OPEN ACCESS

Edited by:

Joanna Cichy,

Jagiellonian University, Poland

Reviewed by:

P. Trayhurn

University of Liverpool,

United Kingdom

Marta Derecka,

Max Planck Institute for

Immunobiology and

Epigenetics, Germany

${ }^{*}$ Correspondence:

Christoph Rummel

Christoph.D.Rummel@

vetmed.uni-giessen.de

Specialty section:

This article was submitted to Cytokines and Soluble Mediators in

Immunity,

a section of the journal

Frontiers in Immunology

Received: 07 April 2020

Accepted: 06 July 2020

Published: 19 August 2020

Citation:

Peek $V$, Neumann E, Inoue T, Koenig S, Pflieger FJ, Gerstberger R, Roth J, Matsumura K and Rummel C (2020) Age-Dependent Changes of

Adipokine and Cytokine Secretion

From Rat Adipose Tissue by Endogenous and Exogenous Toll-Like Receptor Agonists.

Front. Immunol. 11:1800

doi: 10.3389/fimmu.2020.01800

\section{Age-Dependent Changes of Adipokine and Cytokine Secretion From Rat Adipose Tissue by Endogenous and Exogenous Toll-Like Receptor Agonists}

\author{
Verena Peek ${ }^{1}$, Elena Neumann ${ }^{2}$, Tomohiro Inoue ${ }^{3}$, Sandy Koenig ${ }^{1}$, \\ Fabian Johannes Pflieger ${ }^{1}$, Rüdiger Gerstberger ${ }^{1}$, Joachim Roth ${ }^{1,4}$, Kiyoshi Matsumura ${ }^{3}$ \\ and Christoph Rummel ${ }^{1,4 *}$
}

\begin{abstract}
${ }^{1}$ Institute of Veterinary Physiology and Biochemistry, Justus Liebig University Giessen, Giessen, Germany, ${ }^{2}$ Department of Rheumatology and Clinical Immunology, Campus Kerckhoff, Justus Liebig University Gießen, Bad Nauheim, Germany,

${ }^{3}$ Department of Biomedical Engineering, Osaka Institute of Technology, Osaka, Japan, ${ }^{4}$ Joachim Roth and Christoph Rummel, Center for Mind, Brain and Behavior (CMBB), University of Marburg and Justus Liebig University Giessen, Marburg, Germany
\end{abstract}

White adipose tissue but recently also brown adipose tissue have emerged as endocrine organs. Age-associated obesity is accompanied by prolonged and elevated lipopolysaccharide (LPS)-induced sickness symptoms and increased cytokine and adipokine levels in the circulation partially originating from adipose tissue. In the present study, ex vivo fat explants were used to investigate how the exogenous pathogen-associated molecular pattern (PAMP) LPS or the endogenous danger-associated molecular patterns (DAMPs) high mobility group box-1 protein (HMGB1) and biglycan modulate the release of cytokines and adipokines/batokines and, thus, could influence systemic and/or local inflammation. The response of adipose tissue (epididymal, retroperitoneal, subcutaneous, and brown) was compared between young lean and old obese rats (2 vs. 24 months old). LPS induced a strong interleukin (IL)-6 and tumor necrosis factor (TNF) alpha release into the supernatant of all adipose tissue types investigated. HMGB1 (subcutaneous) and biglycan (retroperitoneal) led to an increased release of IL-6 and TNFalpha (HMGB1) and decreased visfatin and adiponectin (biglycan) secretion from epididymal adipose tissue (young rats). Visfatin was also decreased by HMGB1 in retroperitoneal adipose tissue of old rats. We found significantly higher leptin (all fat pads) and adiponectin (subcutaneous) levels in supernatants of adipose tissue from old compared to young rats, whereas visfatin secretion showed the opposite. The expression of the biglycan receptor Toll-like receptor (TLR) 2 as well as the LPS and HMGB1 receptors TLR4 and receptor for advanced glycation end products (RAGE) were reduced with age (TLR4/RAGE) and by stimulation with their ligands (subcutaneous). Overall, we revealed that adipokines/adipose-tissue released cytokines show some modulation of their release caused by mediators of septic (batokines) and 
sterile inflammation with potential implication for acute and chronic disease. Moreover, aging may increase or decrease the release of fat-derived mediators. These data show that DAMPS and LPS locally modulate cytokine secretion while only DAMPS but not LPS can locally alter adipokine secretion during inflammation.

Keywords: adipokines, cytokines, batokines, lipopolysaccharide, high mobility group box-1 protein, biglycan, aging, fat explant cultures

\section{INTRODUCTION}

The term adipose tissue actually covers several subtypes, i.e., white, brown, and beige fat. Histologically, low blood perfusion and cells with a large single lipid droplet are characteristic for white adipose tissue (WAT). Brown adipose tissue (BAT) shows multiple small lipid droplets, large amounts of mitochondria, and dense sympathetic innervation and vascularization and functions as a thermo-effector organ to generate heat during cold exposure and contributes to fever generation during infection and inflammation (1). Interestingly, deposited, structural, or fibrous fat pads (2) can be found in close vicinity to almost every organ system ranging from the kidney [perirenal fat (3)], the gut [mesenteric fat (4)], and joints [infrapatellar fat pads (5)] to the spinal cord (epidural fat) or fat surrounding blood vessels [perivascular fat (6)]. Visceral adipose tissue (VAT), for example, produces higher amounts of molecules of the innate immune system than subcutaneous adipose tissue does (SAT) (7).

Adipose tissue has a multitude of functions, including energy storage and mechanical protection (e.g., kidney). Its role as an endocrine organ emerged at least since the discovery of leptin (8) - the voice of white adipose tissue, a cytokine-like hormone, which inhibits food intake and regulates energy expenditure (9). Indeed, it is now known that adipose tissue can produce and secrete a variety of bioactive factors, including the classical pro-inflammatory cytokines interleukin (IL)-6 and tumor necrosis factor (TNF) $\alpha$ and the adipokines leptin, visfatin, and adiponectin $(10,11)$. Adiponectin increases insulin sensitivity, glucose tolerance, and fatty acid oxidation $(12,13)$. Visfatin regulates insulin secretion via its enzymatic action (14, 15). Visfatin, IL-6, and TNF $\alpha$ are primarily regarded to be proinflammatory, while adiponectin has some anti-inflammatory capacities (10). Visfatin has been shown to induce IL-6 and $\mathrm{TNF} \alpha$ in leukocytes (16) or during adipogenic differentiation of mesenchymal stem cells in vitro (17) and increases circulating IL-6 in vivo in mice (16). Adiponectin inhibits TNF $\alpha$ synthesis by macrophages in vitro (18) or improves clinical parameters in inflammatory animal models like lipopolysaccharide (LPS)induced liver injury in obese mice (19). Leptin rather acts as an immune modulator of the innate and adaptive immune system and, for example, contributes to the LPS-induced brain cytokine response (e.g., $\mathrm{TNF} \alpha)$ in mice $(20,21)$. In turn, through these and other mediators, white adipose tissue plays important roles in immunity, inflammation, and acute phase responses or insulin sensitivity $(22,23)$.

The expression and secretion of adipokines and cytokines depends on the anatomical localization of the fat depot
(24-26) and can be altered by several physiological and pathophysiological factors, which involve the balance of energy storage, hypoxia, and inflammation. Obesity (10) and ageassociated obesity $(27,28)$ are accompanied by larger cell size of adipocytes, higher adipose tissue mass and, therefore, hypoxia, and recruitment of immune cells into the tissue causing inflammation (29-31). The microenvironment partially determines fat depot specific function and secretory activity, which is related to blood flow, cell composition, and innervation (7). Blood supply is dysregulated with aging (32), and aging also leads to fat redistribution with loss of subcutaneous and gain of visceral fat (33). Aging upregulates IL-6 and TNF $\alpha$ expression in mouse adipose tissue (34) while the LPS-induced release of $\mathrm{TNF} \alpha$ from epididymal WAT was reported to be lower in aged than in young rats (35). Overall, obesity (36) and age-related obesity (27) lead to an imbalance of pro- and anti-inflammatory mediators cumulating in a state of low-grade inflammation (10) that has been associated with increase, for example, the risk of cognitive and emotional alterations during infection and inflammation and risk for diabetes and cardiovascular disease (23).

While endocrine function of adipose tissue is now wellestablished, there is increasing evidence that paracrine interaction of molecules produced and released by adipose tissue functionally alters organ systems in close vicinity (like bone or vasculature). However, the physiological significance and potential side-specific function of anatomical fat depots is still not well-understood and remains to be further investigated. As such, one third (15-30\%) of circulating IL-6 is derived from fat (37). SAT was shown to significantly contribute to the systemic increase of IL-6, but TNF $\alpha$ rather seemed to act locally as there was no arteriovenous difference derived from a subcutaneous adipose tissue bed detected in humans (37). Almost all TNF $\alpha$ production and some portion of IL- 6 secretion are due to tissue macrophages in white adipose tissue (38).

Here, we aimed to investigate age-dependent and fat padspecific local release of adipokines or brown adipose tissuederived mediators termed "batokines" $(39,40)$ in rats ex vivo. Stimulation of adipose tissue cultures with the exogenous inflammatory component and toll-like receptor (TLR) 4 ligand LPS, a pathogen-associated molecular pattern (PAMP) and mimetic of bacterial inflammation, was compared to so-called danger-associated patterns (DAMPs). These are endogenous molecules that signal "alarm" to activate the immune system, [for e.g., during chronic inflammation like high-mobility group box protein (HMGB1)] (41) or the extracellular matrix protein biglycan (42). HMGB1 is a ubiquitous nuclear protein that 
seems to play an important role for prolonged inflammation in aseptic (43) and septic-like LPS-induced animal models (44) or arthritis (45) when released into the extracellular space. HMGB1 signals via toll-like receptor (TLR) 4 and the receptor for advanced glycation end products (RAGE). It can, for example, be released by necrotic adipocytes, and it alters the WAT macrophage phenotype to a more pro-inflammatory state (45). Interestingly, WAT HMGB1 expression and plasma levels are higher in obese individuals (46), which seems to be primarily secreted from the stromal vascular portion (47). In addition, the extracellular matrix component biglycan could contribute to the pro-inflammatory status in WAT. Indeed, biglycan expression is increased in WAT of obese women and its expression correlates with pro-inflammatory genes such as TNF $\alpha$ (42). Biglycan signals via TLR2/4 and has been shown to enhance TNF $\alpha$ synthesis in macrophages (48).

Thus, we experimentally stimulated SAT, retroperitoneal WAT (RFAT), epididymal WAT (EFAT), and BAT with LPS, HMGB1, biglycan, or saline in vitro of adult (2 months, young) vs. 24-month-aged (old) rats. We used so-called fatexplant cultures, which have the advantage to preserve a more physiological cross talk between several cell types compared to cell lines, stem cell-derived cultures, or dissociated, purified cultures (49). Explants include adipocytes and the stromal vascular fraction, e.g., immune cells and endothelial cells. As the amount of BAT is very limited in adult and aged rats, we focused on LPS-induced changes for this tissue type. The agedependent release of the cytokines IL- 6 and TNF $\alpha$ and of the adipokines leptin, visfatin, and adiponectin was investigated. Moreover, we analyzed the expression of involved receptors for LPS, HMGB1, and biglycan, namely, TLR2/4 and RAGE, to gain some indication of a functional regulation by age and treatment.

\section{MATERIALS AND METHODS}

\section{Animals}

WAT was withdrawn from animals killed for scientific organ removal in accordance with the German animal protection law and the local Ethics committee "Regional Council Giessen" (ethics approval numbers GI 18/2 Nr. 1/2011, GI 18/2 Nr. 485M, 576_M, 577_M). Male young (2 months) and old (23-24 months) Wistar rats (Rattus sp.) originated from an in-house breeding colony with parental animals obtained from Charles River WIGA (Sulzfeld, Germany). Animals had a body weight of 200-250 g (young) or 600-750 g (old) and were housed at 22 $\pm 2^{\circ} \mathrm{C}, 50 \%$ humidity on a $12: 12$-h light-dark cycle. Rats had ad libitum access to water and standard lab chow with its gross composition as follows: crude protein $21.2 \%$, crude lipids $3.8 \%$, crude fiber $4.4 \%$, crude ash $6.7 \%$, calcium $1 \%$, and phosphorus $0.7 \%$ (ssniff Spezialdiäten GmbH, Soest, Germany).

\section{Fat Explant Cultures}

EFAT dorsal of the testicles, RFAT at the level caudal to the kidneys, inguinal SAT, and BAT derived only from the interscapular depot were dissected under aseptic conditions (70\% ethanol for skin disinfection, Stockmeier $\mathrm{GmbH}$ \& Co. KG, D-Dillenburgand, Germany), and fat explant cultures were performed as previously described $(35,50)$ (see also the scheme/pattern for randomization in the Supplementary Material). In brief, fat tissue was washed in cold PBS and stored on ice in Hank's Balanced Salt Solution (HBSS, $\mathrm{Ca}^{2+}$-, and $\mathrm{Mg}^{2+}$-free, Biochrom AG, D-Berlin)-filled sterile falcon tubes. Tissue was cut into 60 -mg pieces, washed in HBSS, and cultured in 12-well plates with prewarmed fetal calf serum (FKS, PAA GmbH, A-Pasching, Germany) supplemented with Dulbecco's Modified Eagle Medium: Nutrient Mixture F-12 (DMEM/F12, Invitrogen, D-Darmstadt, Germany) medium at $37^{\circ} \mathrm{C}$ (95\% humidity, $5 \% \mathrm{CO}$, and $95 \%$ air) for $24 \mathrm{~h}$. The next day, fat tissue was washed with FKS-free medium and incubated with $100 \mathrm{ng} / \mathrm{ml}$ LPS (E. coli, serotype 0111:B4, Lot: 043M4104, Sigma-Aldrich Chemie GmbH, D-München, Germany), $1 \mu \mathrm{g} / \mathrm{ml}$ biglycan (biglycan from bovine articular cartilage, Lot: 033M4046V, Sigma-Aldrich Chemie GmbH, D-München), $1 \mu \mathrm{g} / \mathrm{ml}$ HMGB1 (disulfide High-Mobility Group Box-1, LPS free (HMGB1), Lot: 170823, 18050P, 180720, 671121 HMGBiotech S.r.l., Mailand, Italy), or PBS dissolved in DMEM/F12 without FKS. BAT was stimulated with LPS $[10 \mu \mathrm{g} / \mathrm{ml}]$ or PBS only. Supernatant was collected $24 \mathrm{~h}$ after stimulation and stored at $-55^{\circ} \mathrm{C}$ for later analysis of adipokines/batokines and cytokines. LPS dose and time of incubation were chosen according to previous results showing a significant increase in IL-6, TNF $\alpha$, and IL-1ra secretion into the supernatant, when compared to PBS controls $(35,50)$. Ten $\mu \mathrm{g} / \mathrm{ml}$ LPS of the same serotype of LPS has previously been shown to robustly increase the secretion of cytokines from primary hypothalamic (51) and dorsal root cell cultures (52). Such a response was confirmed in preliminary dose-response experiments for BAT. Basal secretion of interleukin (IL)-6 was similar to other tissue sources indicating similar viability (Supplementary Figure 1). We selected the LPS dose that induced a similar range of response as observed in SAT for LPS-induced IL-6 secretion. Thus, $10 \mu \mathrm{g} / \mathrm{ml}$ LPS was chosen for treatment of BAT explant cultures. Moreover, previous studies revealed that HMGB1 and biglycan are biologically active at $\sim 1 \mu \mathrm{g} / \mathrm{ml}$ concentration $(53,54)$. Intact cytoarchitecture was confirmed by hematoxylin and eosin stain or immunofluorescence staining of the explant tissue after culture (Supplementary Figures 2-4). Moreover, a colorimetric viability MTT assay was used to confirm that viability of all anatomical adipose tissue fat pads after dissections and before addition of PAMPs and DAMPs was similar (data not shown). As expected, the MTT assay also revealed that the metabolic activity of adipose tissue from aged rats was overall lower than from young rats (just after tissue withdrawal) and BAT had higher metabolic activity than WAT. All solution and buffers were supplemented with penicillin/streptomycin (Thermo Fisher Scientific Inc., Waltham, MA, USA) to prevent bacterial growth in case of contamination. The wet weight of fat tissue was used for normalization of mediators per $\mathrm{ml}$ supernatant and tissue frozen for further PCR analyses.

\section{Real-Time PCR}

Total RNA was extracted from each sample (three 60-mg pieces of cultured fat tissue) with TRIzol (Invitrogen, Carlsbad, CA) according to the manufacturer's protocol. Reverse transcription 
was performed on $1 \mu \mathrm{g}$ of total RNA in a total reaction volume of $20 \mu \mathrm{l}$ with $\mathrm{M}-\mathrm{MLV}$ reverse transcriptase (50 U), dNTP mix $(10 \mathrm{mM})$, and random hexamers $(50 \mu \mathrm{M}$; Applied Biosystems, Foster City, CA). Applied Biosystems TaqMan Gene Expression Assays and TaqMan Gene Expression Master Mix were used on a StepOnePlus Real-Time PCR System (Applied Biosystems) for relative quantification of mRNA in duplicate. Out of six reference genes tested (18S, B2M, $\beta$-actin, CANX, GAPDH, UBC; Reference Gene Assay with double-dye probe, PrimerDesign Ltd., Southampton, UK), the NormFinder software revealed $\beta$-actin as the most stable housekeeping gene for normalization of cDNA quantities. The $2^{-(\Delta \Delta \mathrm{Ct})}$ method was applied to calculate relative expression, and data is presented as relative quantity as previously reported $(35,55)$. The sample values represent $\mathrm{x}$-fold differences from a control sample (given as a designated value of 1 ) within the same experiment. Analyzed genes were used with assay IDs as follows (Thermo Fisher Scientific Inc., Waltham, MA, USA): $\beta$-actin (Rn00667869_m1); HMGB1 (Rn00566331_m1); RAGE (Rn00584249_m1); TLR2 (Rn02133647_s1); and TLR4 (Rn00569848_m1). Sample numbers used for PCR are listed in Table 1.

\section{Measurement of Cytokines and Adipokines/Batokines}

FAT-explant supernatants were analyzed for levels of IL-6 and $\mathrm{TNF} \alpha$ using bioassays and adipokines/batokines including leptin, visfatin, and adiponectin using ELISA. The bioassays are based on a cytotoxic effect of TNF $\alpha$ on the WEHI 164 subclone 13 mouse fibrosarcoma cell line and dosedependent growth stimulation of the B9 hybridoma cell line by IL- 6 as previously reported (56). Detection limits are $3 \mathrm{IU} \mathrm{IL}-6 / \mathrm{ml}$ and $6 \mathrm{pg} \mathrm{TNF} / \mathrm{ml}$. Adipokine levels were analyzed according to the manufacturer's instructions by ELISA (mouse/rat Visfatin/NAMPT RAG009R, BioVendor; mouse/rat Leptin MOB00; and rat total Adiponectin/ACrp30 Quantikine ELISA, R\&D Systems). The assay ranges were 62.5$4,000 \mathrm{pg} / \mathrm{ml}$ for leptin (sensitivity $22 \mathrm{pg} / \mathrm{ml}$ ), $0.5-32 \mathrm{ng} / \mathrm{ml}$ for visfatin (sensitivity $50 \mathrm{pg} / \mathrm{ml}$ ), and $0.2-10 \mathrm{ng} / \mathrm{ml}$ for adiponectin (sensitivity $0.023 \mathrm{ng} / \mathrm{ml}$ ). Sample numbers are listed in Table 2.

\section{Immunohistochemistry of TNF $\alpha$ and Macrophages in SAT}

Adipose tissue explants were immediately snap frozen after use in culture. For immunohistochemistry, frozen tissue samples were fixed overnight in $4 \%$ formalin. Tissues were then embedded in paraffin. Five micrometer sections were prepared and deparaffinized followed by rehydration. Tissues were pretreated by boiling tissues in $10 \mathrm{mM}$ citrate buffer (0.05\% Tween, $\mathrm{pH} 6.0$ ) and blocked for endogenous peroxidase activity and unspecific bindings using 5\% BSA. Primary antibody (unconjugated mouse anti-human/rat TNF- $\alpha$ NBP2-45331 NovusBio; dilution 1:100 or AF3667 R\&D Systems, goat anti-human/mouse-rat myeloperoxidase/MPO antibody) or isotype control (mouse IgM Kappa isotype MCA692 Serotec or normal goat IgG control) was incubated overnight at $4^{\circ} \mathrm{C}$. Sections were incubated for
30 min with the respective Histofine detection system (Medac). For visualization, the AEC kit was used (Vector-Laboratories). Isotype control and negative control without primary antibody were negative (no red/brown signals).

\section{Immunofluorescence Staining of Macrophages in BAT}

BAT was withdrawn from old and young rats of the interscapular depot, snap frozen in liquid nitrogen, cut into $20-\mu \mathrm{m}$ sections (HM 500, Microm, Walldorf, Germany), thaw-mounted on polyL-lysine-coated glass slides, and immediately used for staining. Sections were air-dried at room temperature (RT), labeled, and immersion-fixed for $10 \mathrm{~min}$ at RT in $2 \%$ paraformaldehyde (Merck, Darmstadt, Germany), diluted in PBS. Sections were washed three times in PBS and incubated at RT for $1 \mathrm{~h}$ with blocking solution [PBS, $10 \%$ normal donkey serum (NDS; Biozol, Eching, Germany), 0.1\% Triton X-100 (Sigma-Aldrich)]. The rabbit anti-MPO antibody (A0398 Dako, rabbit antihuman MPO) was used at 1:200 dilution and incubated in a humid chamber for $24 \mathrm{~h}$ at $4^{\circ} \mathrm{C}$. After three washes in PBS, macrophages were visualized by 2 -h incubation at RT with Alexa-488-conjugated anti-rabbit IgG (1:500; cat. L110A-ABP, MoBiTec GmbH, Göttingen, Germany). Glycerol/PBS solution (Citifluor, LTD, London, UK) was used as mounting medium to coverslip (glass cover slips) slides. Microscopic analysis was performed using a conventional light/fluorescent Olympus BX50 microscope (Olympus Optical, Hamburg, Germany) and a black and white Spot Insight camera (Diagnostic Instruments, Visitron Systems, Puchheim, Germany) was used to take microphotographs (MetaMorph 5.05 software). Brightness and contrast were adjusted (Adobe Photoshop 5.05). Specificity of the signals of the primary antibodies has been confirmed in previous experiments (57).

\section{Colorimetric Viability MTT Assay}

Viability and metabolic activity of explant tissue from all anatomical fat pads of young and old rats after dissection and $24 \mathrm{~h}$ after culture was assessed by dimethylthiazoldiphenyl tetrazolium bromide MTT (M5655, Sigma-Aldrich) colorimetric assay.

\section{Data Analysis}

For statistical analyses, fat explant cytokine and adipokine levels from supernatants were averaged as means (for threefour separate experiments and two-four wells/treatment and experiment) of the means \pm SEM of each experimental group for statistical analysis. Relative expressions of HMGB1, RAGE, TLR2, and TLR4 of fat adipose tissue were analyzed with treatment (LPS/HMGB1/biglycan vs. control) and age (young vs. old) by two-way ANOVA (Prism 5 software; GraphPad, San Diego, CA). Bonferroni post hoc tests were conducted if a significant interaction was revealed. Data that was outside of an acceptable variance was excluded by outlier testing. Significance was set for $P \leq 5 \%$. Data are illustrated as mean \pm SEM. 
TABLE 1 | Number of samples used for PCR as well as the number of preparations from which these samples were obtained.

Stimulation Samples Experiments Stimulation Samples Experiments

\begin{tabular}{|c|c|c|c|c|c|}
\hline \multicolumn{3}{|c|}{$\begin{array}{l}\text { Subcutaneous adipose tissue of } \\
\text { young rats }\end{array}$} & \multicolumn{3}{|c|}{$\begin{array}{l}\text { Subcutaneous adipose tissue of } \\
\text { old rats }\end{array}$} \\
\hline PBS & 3 & 3 & PBS & 4 & 4 \\
\hline LPS & 3 & 3 & LPS & 4 & 4 \\
\hline HMGB1 & 3 & 3 & HMGB1 & 4 & 4 \\
\hline Biglycan & 3 & 3 & Biglycan & 4 & 4 \\
\hline
\end{tabular}

\section{RESULTS}

\section{Age-Dependent LPS-Induced IL-6 and TNF $\alpha$ Secretion of Fat Explant Cultures}

We compared the effects of LPS stimulation in EFAT, RFAT, SAT, and BAT on the secretion of IL-6 and TNFa $24 \mathrm{~h}$ after treatment compared to solvent controls. LPS increased levels of both cytokines in all different fat pads investigated (Figures 1A,B). Interestingly, IL-6 secretion was significantly enhanced in SAT while it was significantly reduced in BAT of aged rats compared to young counterparts (Figure 1A). LPSinduced TNF $\alpha$ secretion was significantly lower in EFAT and RFAT of old rats compared to young counterparts (Figure 1B). In addition, by means of immunohistochemistry, we demonstrated TNF $\alpha$ immunoreactivity in macrophages of the explants in LPSstimulated tissue. This result shows that macrophages rather than adipocytes are the source of TNF $\alpha$ measured in the supernatants (Supplementary Figures 3A,B). Interestingly, the number of MPO-immunoreactive macrophages did not seem to increase but may potentially even decrease in BAT with age (Supplementary Figure 4).

\section{Age-Dependent HMGB1/Biglycan-Induced IL-6 and TNF $\alpha$ Secretion of Fat-Explant Cultures}

Sterile inflammatory insults commonly occur and may affect adipose tissue cytokine secretion. Thus, we applied two candidates that have been shown to play a role during sterile inflammation and to be more expressed in WAT of obese individuals $(42,45)$. For HMGB1, we revealed a clear fat padspecific effect with strongest changes observed in subcutaneous adipose tissue for IL-6 and TNF $\alpha$ secretion (Figures 2A,B). While a main effect of age and treatment was found also for RFAT, we only detected a significant HMGB1-induced increase of IL-6/TNF $\alpha$ in the supernatants of explant cultures in SAT of young (IL-6) and old (IL-6 and TNF $\alpha$ ) rats. This response was significantly enhanced by aging for IL-6 (Figure 2A), which is similar to observed changes after LPS stimulation for IL- 6 but not for $\mathrm{TNF} \alpha$, suggesting some heightened inflammatory response by aging in particular in SAT. A somehow similar response appeared after biglycan stimulation (Figures 2C,D). IL-6 (RFAT and SAT)/TNF $\alpha$ (RFAT) levels in the supernatants showed a main effect of treatment and age. However, post hoc tests only revealed higher basal levels and a significant induction of IL- 6 in RFAT of
TABLE 2 | Number of samples used for adipokine/batokine and cytokine measurements and the number of preparations from which they were obtained.

Stimulation Samples Experiments Stimulation Samples Experiments

\begin{tabular}{|c|c|c|c|c|c|}
\hline Young rats & & & Old rats & & \\
\hline \multicolumn{6}{|c|}{ Epididymal adipose tissue (EFAT) } \\
\hline PBS & 9 & 3 & PBS & 9 & 3 \\
\hline LPS & 9 & 3 & LPS & 6 & 3 \\
\hline HMGB1 & 9 & 3 & HMGB1 & 9 & 3 \\
\hline Biglycan & 9 & 3 & Biglycan & 9 & 3 \\
\hline \multicolumn{6}{|c|}{ Retroperitoneal adipose tissue (RFAT) } \\
\hline PBS & 9 & 3 & PBS & 9 & 3 \\
\hline LPS & 9 & 3 & LPS & 6 & 3 \\
\hline HMGB1 & 9 & 3 & HMGB1 & 9 & 3 \\
\hline Biglycan & 9 & 3 & Biglycan & 9 & 3 \\
\hline \multicolumn{6}{|c|}{ Subcutaneous adipose tissue (SAT) } \\
\hline PBS & 9 & 3 & PBS & 12 & 4 \\
\hline LPS & 6 & 3 & LPS & 8 & 4 \\
\hline HMGB1 & 9 & 3 & HMGB1 & 12 & 4 \\
\hline Biglycan & 9 & 3 & Biglycan & 12 & 4 \\
\hline \multicolumn{6}{|c|}{ Brown adipose tissue (BAT) } \\
\hline PBS & 5 & 4 & PBS & 11 & 3 \\
\hline LPS & 14 & 4 & LPS & 12 & 3 \\
\hline
\end{tabular}

young rats (Figure 2C). Similar to LPS, TNF $\alpha$ levels were lower after biglycan stimulation in aged rats of EFAT (Figure 2D).

\section{Age-Dependent Secretion of Adiponectin, Leptin, and Visfatin From Fat-Explant Cultures After LPS-Stimulation}

In addition to classical cytokines, we aimed to investigate agedependent secretion of the adipokines/batokines adiponectin, leptin, and visfatin in explant cultures after stimulation with the bacterial mimetic LPS. Adiponectin levels in supernatants of these cultures were higher in SAT of old rats compared with young rats (main effect of age) while its levels were not altered by age for EFAT, RFAT, and BAT (Figure 3A). Leptin secretion was higher per gram fat in supernatants of all analyzed fat pads (Figure 3B) while visfatin secretion (Figure 3C) was decreased in fat of old vs. young rats for EFAT, RFAT, and BAT (main effects of age). LPS treatment reduced visfatin levels in supernatants of EFAT (main effect of treatment) but did not significantly alter leptin or adiponectin levels in supernatants of any fat explant culture analyzed.

\section{Age-Dependent Secretion of Adiponectin, Leptin, and Visfatin From Fat-Explant Cultures by the DAMPs HMGB1 and Biglycan}

Similarly, we aimed to investigate if the two DAMPs HMGB1 and biglycan can alter adipokine secretion (Figure 4). The results were comparable to those observed after LPS stimulation, confirming that adiponectin levels mainly show an effect due to 


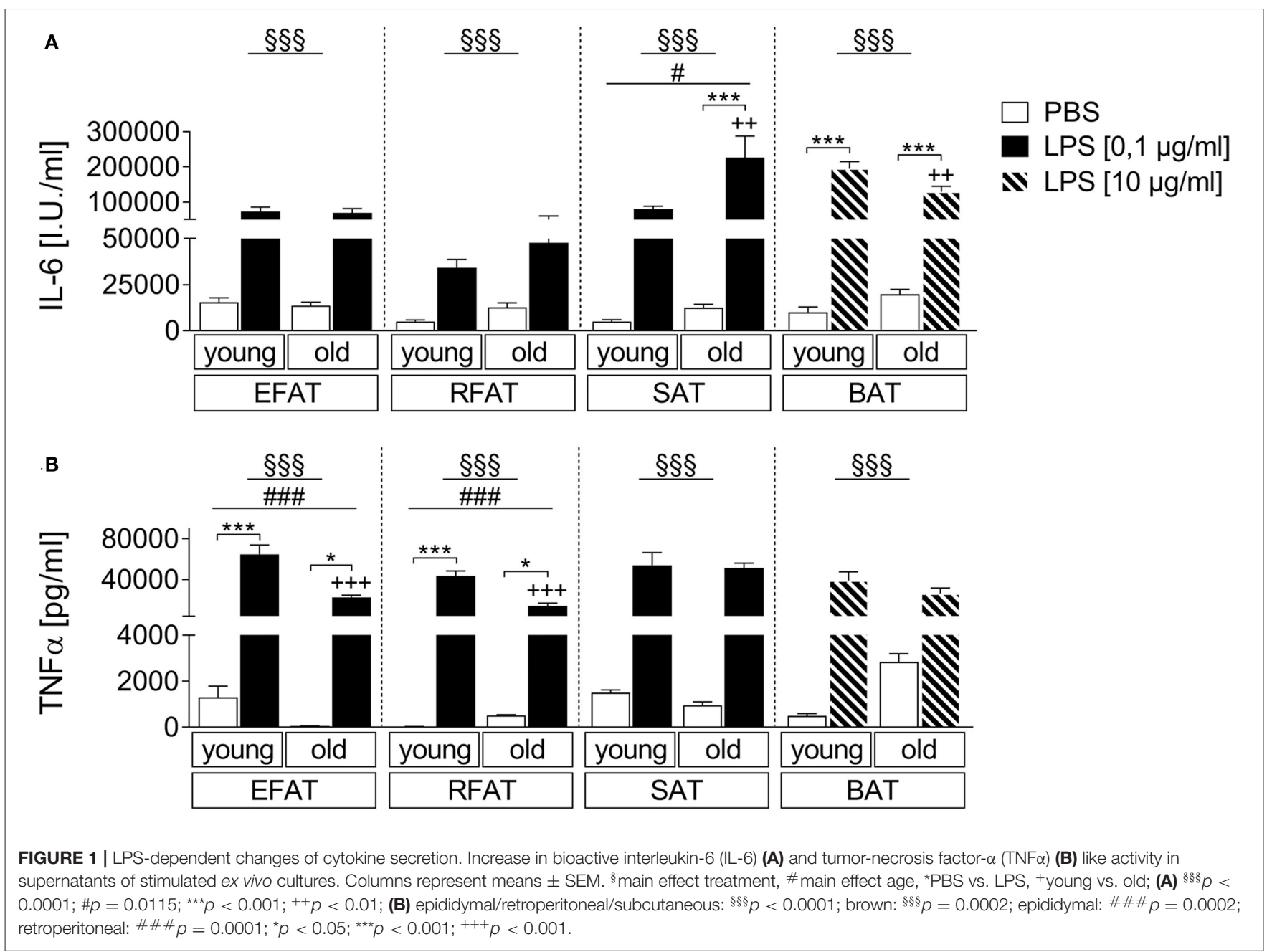

age with overall higher levels in supernatants of aged rats only in SAT (Figures 4A,D). However, biglycan had a significant effect on adiponectin secretion and reduced its levels in EFAT of young but not old rats. Leptin secretion confirmed to be increased in aged rats (main effect of age) but was not altered by HMGB1 or biglycan (Figures 4B,E). For visfatin (Figures 4C,F), overall lower levels were found in WAT of aged rats (EFAT, RFAT). Interestingly, HMGB1 (EFAT, RFAT) and biglycan stimulation (EFAT) significantly reduced visfatin secretion in WAT of young (EFAT, HMGB1, and biglycan) or aged (RFAT, HMGB1) rats.

\section{HMGB1 and Receptor Expression for DAMPS and LPS in SAT of Young and Old Rats and Its Modulation by LPS/HMGB1/Biglycan Stimulation}

To get some insights in potential changes in receptor expression of all stimulants applied in the current study, RAGE, TLR2, and TLR4 mRNA expression was analyzed in SAT as some of the most pronounced changes for cytokines were revealed in this fat pad (Figure 5). HMGB1 mRNA expression was significantly altered neither by age nor by treatment (Figures $\mathbf{5 A - C}$, only main effect of age in B). RAGE expression (Figures 5D-E) was reduced in SAT of aged rats (main effect of age) and was also reduced by LPS treatment (main effect of treatment) with some tendency for its second ligand HMGB1 (significant lower mRNA levels in aged vs. young SAT).

TLR2-mRNA expression (Figures 5G-I) was significantly higher in aged compared to young SAT (main effect of age). Moreover, its expression was significantly reduced by DAMP treatment (main effect of treatment; significant reduction for aged SAT after biglycan treatment as revealed by post hoc test). In contrast to these effects, the LPS receptor mRNA expression (Figures 5J-L) was reduced by treatment with its ligand, while DAMP did not alter its expression. Unlike TLR2 expression, TLR4 expression was reduced in SAT of aged rats compared to their young counterparts (main effect of age).

\section{DISCUSSION}

In our current study, we characterized the age and fat pad-specific potential of the exogenous PAMP LPS and the 


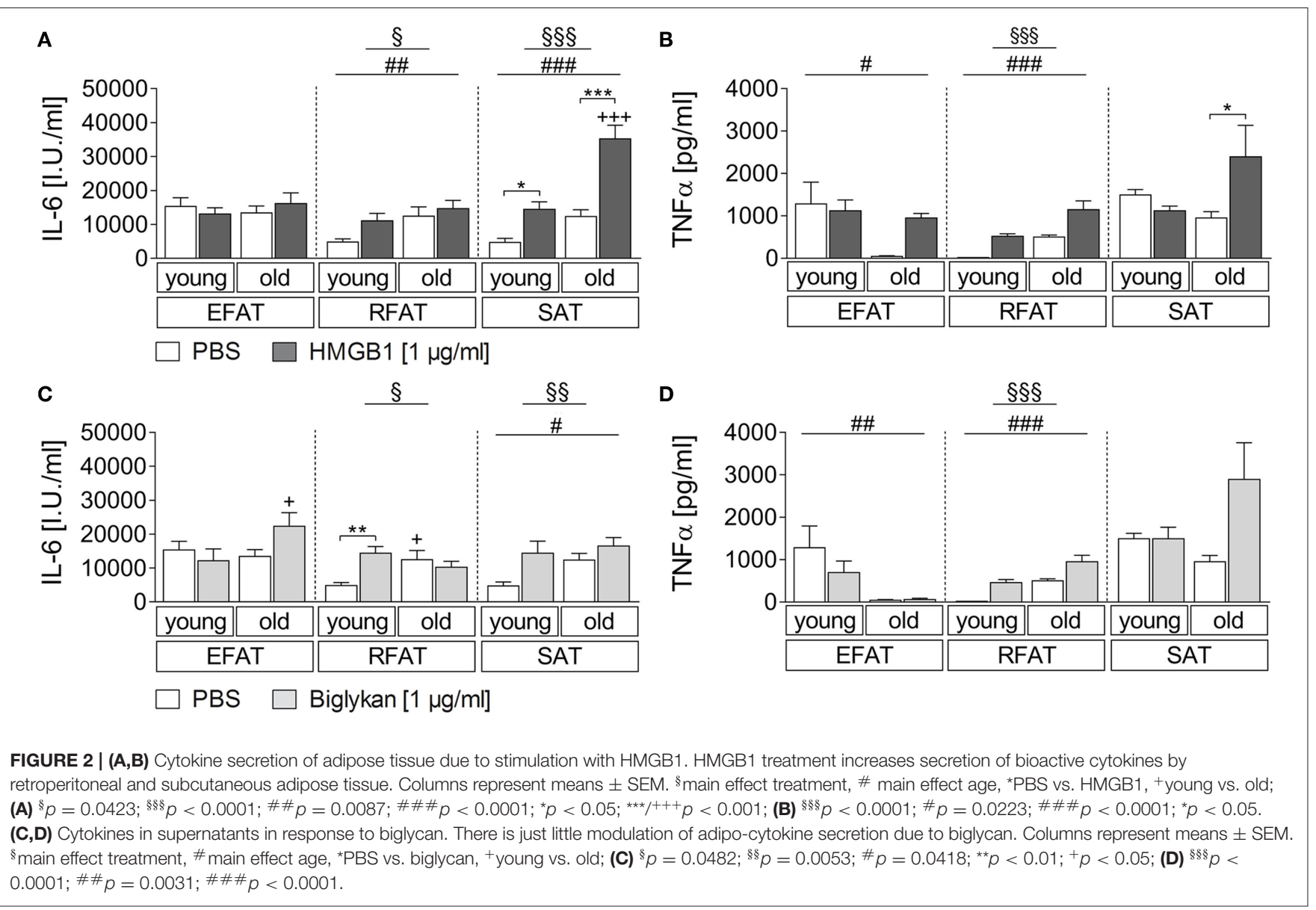

endogenous DAMPs HMGB1 and biglycan on local cytokine and adipokine/batokine secretion from RFAT, EFAT, SAT, and BAT. For the first time, the full characterization revealed that cytokine secretion can be stimulated by both exogenous and endogenous stimuli of the innate immune system, in a regionspecific and comparable manner. We show enhanced LPSinduced upregulation or downregulation of IL-6 (SAT vs. BAT) or $\mathrm{TNF} \alpha$ (EFAT, RFAT) secretion in fat tissue of aged vs. young rats. HMGB1 stimulated a similar response in SAT on IL-6 secretion while biglycan-induced IL-6 secretion was mainly observed in RFAT. Adipokine secretion was altered by age, i.e., increased adiponectin (SAT) and leptin (all fat pads) secretion and reduced visfatin release from all fat pads analyzed except for SAT. While LPS treatment did not influence adipokine secretion, the DAMPs HMGB1 and biglycan reduced visfatin secretion in EFAT (HMGB1 and biglycan) and RFAT (HMGB1) and adiponectin secretion in EFAT (biglycan). Interestingly, HMGB1 and LPS receptor expression (RAGE, TLR4) was significantly reduced and the biglycan receptor TLR2 was upregulated in SAT of aged rats. Stimulation with DAMPs significantly reduced the expression of their receptor in SAT of rats, suggesting some potential downregulation after their activation.

Normal plasma LPS levels can be detected around $\sim 20-$ $40 \mathrm{pg} / \mathrm{ml}$ in humans (58) and $\sim 600-1,000 \mathrm{pg} / \mathrm{ml}$ in rodents
(59) and increase to $>1 \mu \mathrm{g} / \mathrm{ml}$ during experimental LPS-induced endotoxemia (e.g., $1.9 \mathrm{mg} / \mathrm{kg}$ ) in mice (60) or to $10-200 \mathrm{ng} / \mathrm{ml}$ in septic human patients $(60,61)$. Moreover, local levels in tissue may be even higher during bacterial infection. Indeed, circulating LPS is increased in obese due to enhanced gut permeability and may alter WAT directly (59). Previous studies have also shown that adipose tissue-derived cytokines contribute to circulating cytokine levels during LPS-induced systemic inflammation (37). Moreover, fat tissue in aged obese is a significant source of circulating cytokines and adipokines during systemic inflammation (62) but can also alter tissue in close vicinity in a paracrine manner $(4,5,63)$. Several previous studies have used in vivo systemic LPS stimulation in mice or pigs and revealed an increased expression for example of IL6 and TNF $\alpha$ in adipose tissue (64-66). Others have applied fat explant cultures in cows (67), mice (68), and rats (35) and have shown LPS-induced expression and release of IL-6/TNF $\alpha$. Peripheral action of LPS directly on adipose tissue using fatexplant cultures revealed that white adipose tissue of dietinduced obese rats secretes significantly higher amounts of IL-6 per $g$ fat than from lean controls (50). Enhanced LPS-induced IL6 expression or secretion in fat tissue after in vivo (62) or ex vivo (explant cultures) LPS stimulation, respectively, has previously been shown in aged mice compared to young counterparts and may be related to IL-1 $\beta$ action in aged EFAT (68). Recently, we 


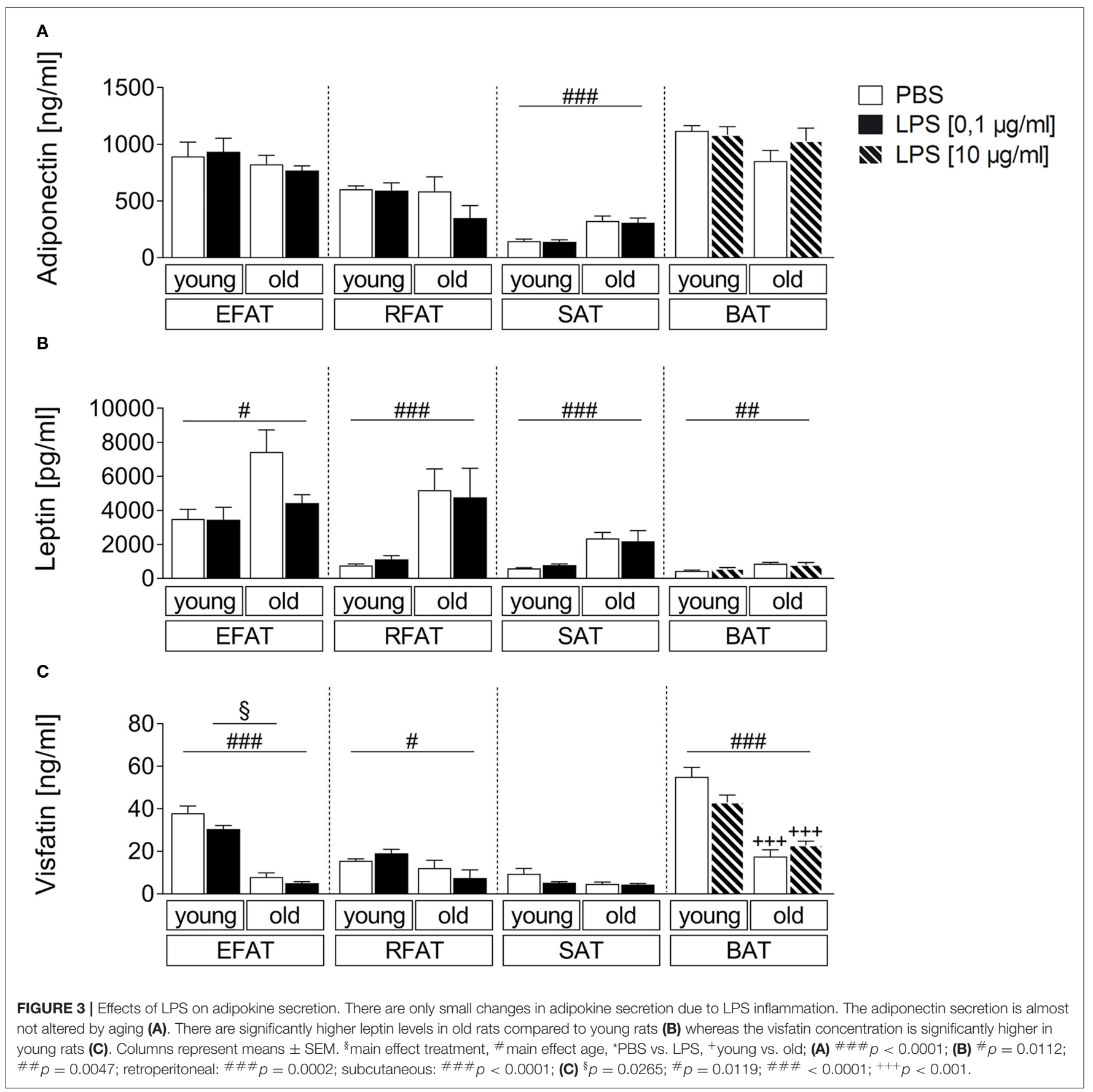

have shown that aging-associated obese rats secret lower TNF $\alpha$ levels and a tendency of higher IL-6 levels per $g$ fat than young counterparts (35). Here, we found that a significantly augmented IL-6 production from aged fat tissue is primarily present in SAT fat pads after both LPS or HMGB1 stimulation. According to the present results, some relevance for subcutaneous tissue is suggested. Interestingly, LPS-induced IL-6 expression was less increased in aged BAT compared to that of young animals.

Our present results further showed that LPS-stimulated $\mathrm{TNF} \alpha$ secretion was lower in EFAT and RFAT of aged rats compared to corresponding tissue of young counterparts, confirming previous results for EFAT (35). Such an agedependent response was less evident after HMGB1 or biglycan stimulation (main effects of age) but may be overall related to reduced functionality of resident or immigrated macrophages in the aged. Indeed, it was previously shown that almost all TNF $\alpha$ expression in adipose tissue arises from resident macrophages (38). Moreover, LPS-induced TNF $\alpha$ levels in primary human monocyte cultures were lower in aged individuals than in young adults (69). Thus, weaker LPS-induced TNF $\alpha$ release 


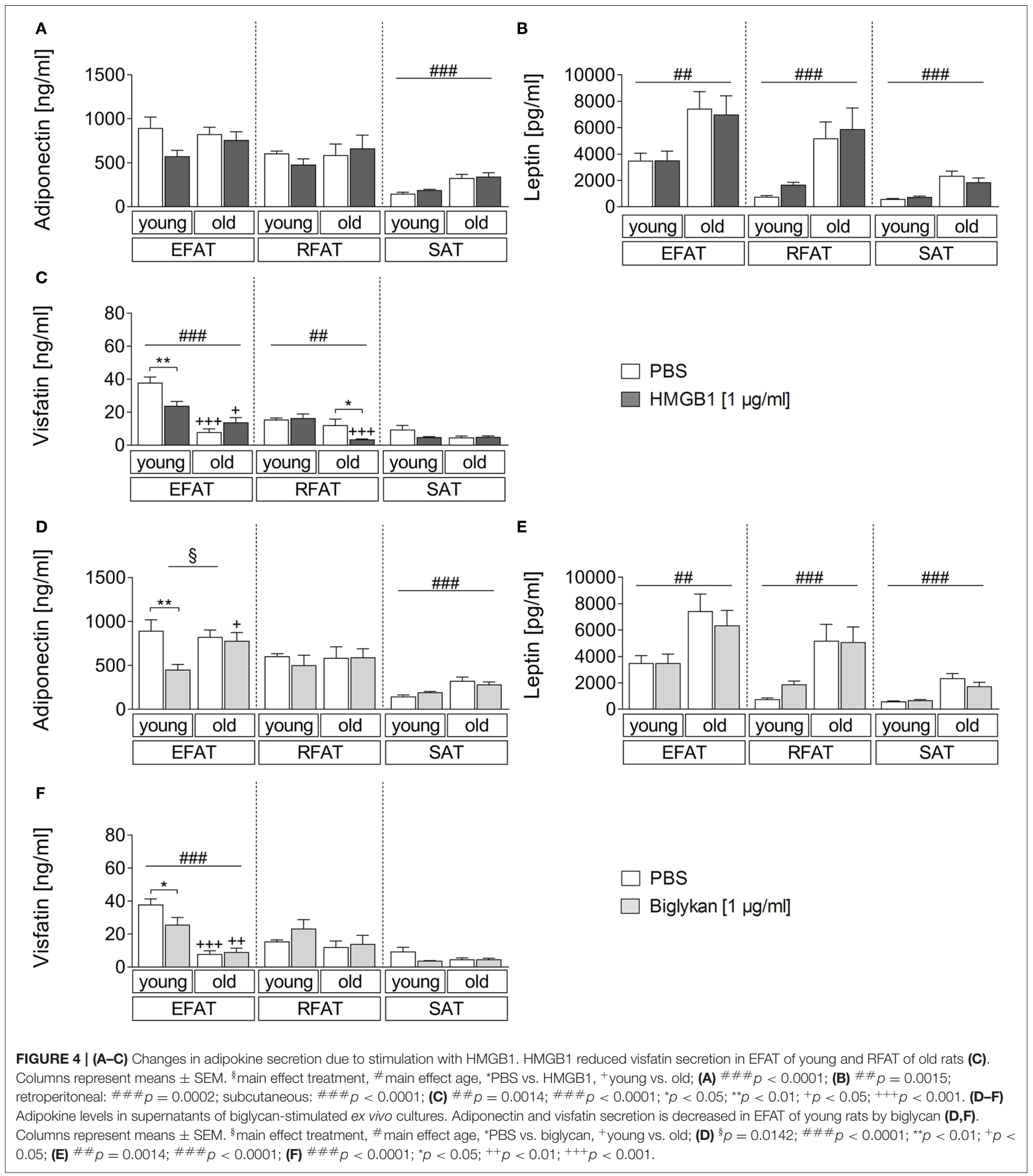

from EFAT and EFAT of aged compared to young rats is most likely related to some loss of secretory capacities of "aged" resident macrophages.

Interestingly, using clodronate liposomes to deplete macrophages, previous studies have shown that M1 macrophages can suppress uncoupling protein (UCP) one expression, a marker for brown adipocytes, via $\mathrm{TNF} \alpha$-mediated mechanisms (70). Moreover, numbers of infiltrating macrophages may differ between anatomical fat pads inhibiting so-called browning of white adipose tissue (71), potentially explaining some of 
A
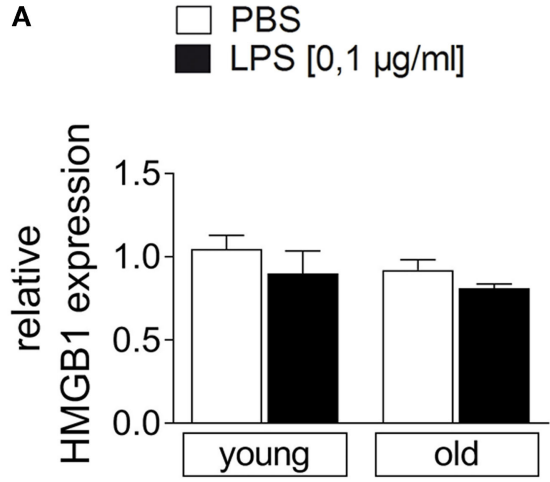

D

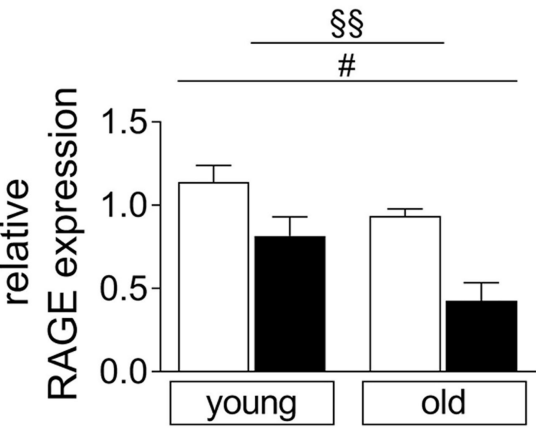

G

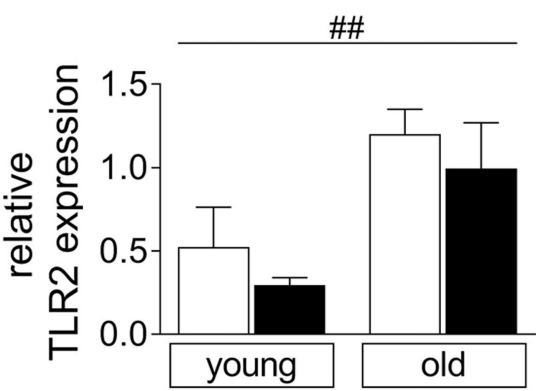

$\mathbf{J}$

$\S \S$

\#\#

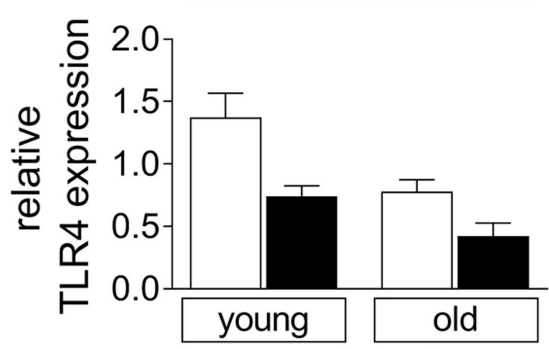

B

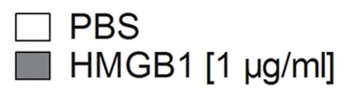

\#

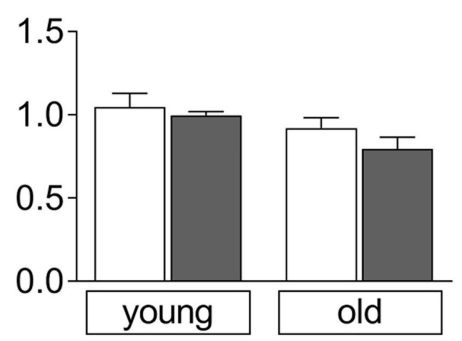

E

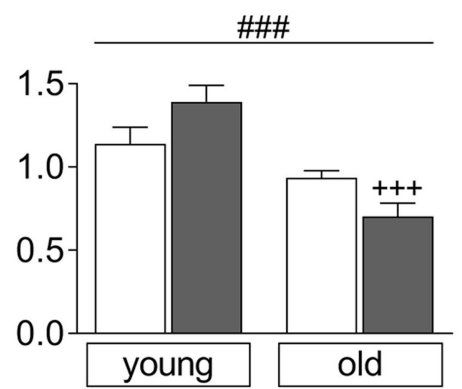

H
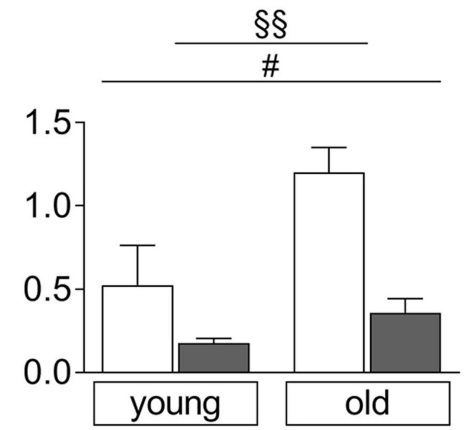

K

\#\#\#

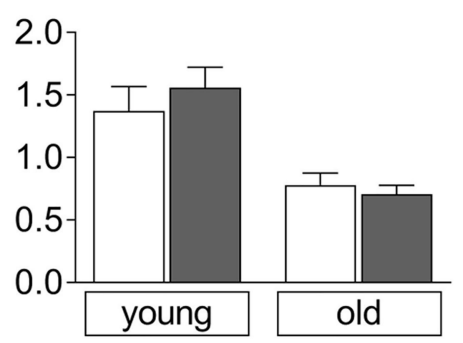

PBS

Biglykan [1 $\mathrm{gg} / \mathrm{ml}]$

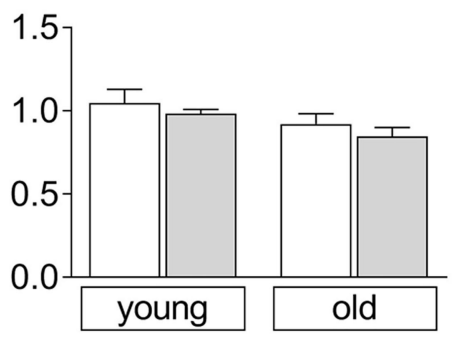

$\mathbf{F}$

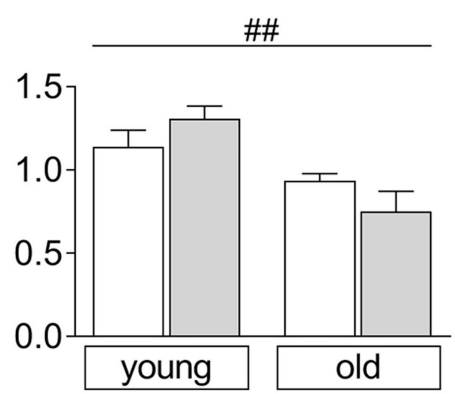

I

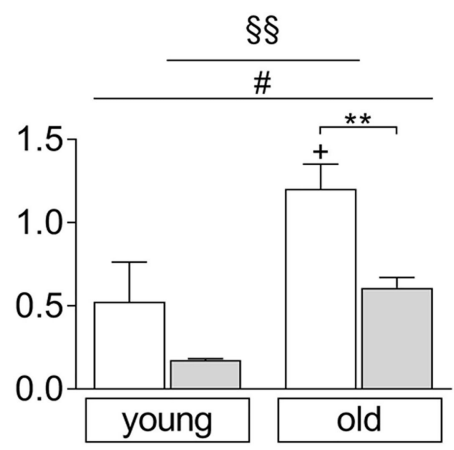

$\mathbf{L}$

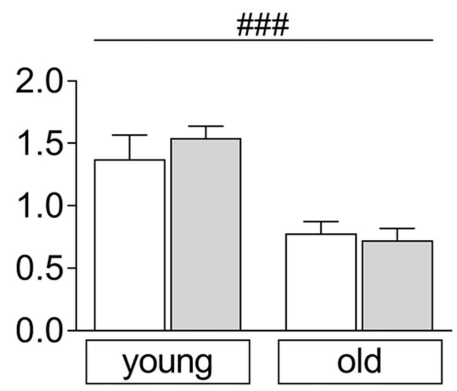

FIGURE 5 | Relative expression of HMGB1 (A-C), RAGE (D-F), TLR2 (G-I), and TLR4 (J-L) in the subcutaneous adipose tissue of young and old rats after stimulation with LPS, HMGB1, or biglycan compared to PBS-incubated control cultures. The relative expression is presented as the mean \pm SEM. White bars show the relative expression $24 \mathrm{~h}$ after incubation with PBS, and the filled bars show the relative expression after incubation with LPS (black), HMGB1 (dark gray), or 
FIGURE 5 | biglycan (light gray). The relative expression of HMGB1, RAGE, and TLR4 showed a statistically significant age-dependent main effect with a lower expression in the adipose tissue of old rats compared to the adipose tissue of young rats. In contrast, there was a significantly higher expression of TLR2 in the adipose tissue of old rats than in the adipose tissue of young rats. Incubation with LPS resulted in a significant reduction in the expression of RAGE and TLR4. Incubation with HMGB1 and biglycan caused a significant reduction in the expression of TLR2. The number of samples used for the PCR is shown in Table 1. ${ }^{\S}$ main effect treatment; ${ }^{\#}$ main effect age; ${ }^{*}$ PBS vs. TLR agonist; ${ }^{+}$young vs. old; (B) ${ }^{\S \S} p=0.0013 ;{ }^{*} p=0.0102 ;$ (C) ${ }^{\# \#} p=0.0083 ;$ (D) ${ }^{\S \S} p=0.0024 ;{ }^{\# \#} p=0.0038 ;(\mathbf{E})$ ${ }^{\#} p=0.0329 ; \mathbf{( F )}{ }^{\# \# \#} p=0.0002 ;{ }^{+++} p<0.001 ;(\mathbf{G}){ }^{\S \S} p=0.0037 ;{ }^{*} p=0.0193 ;(\mathbf{H}){ }^{\# \# \#} p=0.0002 ;(\mathbf{J}){ }^{\# \#} p=0.0022 ;(\mathbf{K}){ }^{\S \S} p=0.0012 ;{ }^{\#} p=0.0426 ;{ }^{* \star} p<$ $0.01 ;+p<0.05$.

the observed differences in the inflammatory response in fat depots to PAMPs and DAMPs. Indeed, TNF $\alpha$ can suppress the activity of the UCP1 promoter (72). In addition, LPS-induced inflammation previously also inhibited UCP1 expression in BAT in vivo (73). Using coculture experiments of brown and white adipocytes with macrophages, Dowal et al. (74) revealed that these immune cells may only enhance inflammatory response in WAT while inflammation seems to be unchanged or could potentially even be inhibited in BAT (74). However, such in vitro experiments will need further confirmation for their functional significance in future studies. Overall, cytokines and LPS can alter BAT-specific gene expression. Here, we have some indication that aging of BAT in rats may not be associated with increased but rather with decreased numbers of macrophages labeled with myeloperoxidase (Supplementary Figure 4). The functional significance may pertain to inhibition or modulation of inflammatory responses as discussed above but remains to be further investigated.

We and others have previously reported that circulating leptin concentrations increase during LPS-induced systemic inflammation in rodents $(21,23,35,75-79)$ and humans $(80,81)$, acting as a neuroimmune mediator and contributing to sickness responses like fever $(35,82)$ or the recruitment of neutrophil granulocytes to the brain $(21,83)$. However, leptin secretion seems to be primarily neuronally controlled (84). Thus, our present results that leptin levels did not increase in supernatants of fat explant cultures may be due to the fact that neuronal control is disrupted in this model system.

Like leptin, visfatin plasma levels have been reported to increase during LPS-stimulated systemic inflammation in rats (85) and humans (86) and may induce production of IL-6 and $\mathrm{TNF} \alpha$ (16). Our present results confirm that release of visfatin is more pronounced from visceral adipose tissue compared to SAT (24). Interestingly, visfatin secretion was rather reduced by LPS stimulation in fat explant cultures, which might be related to other sources in vivo like neutrophil granulocytes that show increased levels in septic patients compared to healthy controls (87).

LPS-induced effects on the mainly anti-inflammatory adipokine adiponectin have been reported to range from reduced circulating levels in mice $(64,88)$, rats $(89)$, and dogs (90) to no changes in humans $(81,91)$. Here, we did not find any effects of LPS on adiponectin secretion. Such differences between studies may be related to the dose and serotype of given LPS or species specifics. Interestingly, we consistently revealed that the release of adiponectin increases in SAT of old rats, which may not suffice to overall increase circulating levels with age.
In addition to white adipose tissue, brown adipose tissue is emerging as a secretory organ that may convey its beneficial effects on insulin sensitivity and metabolism not only via its thermogenic function but also by brown adipokines also termed "batokines" $(39,40)$. Indeed, transplantation of BAT in mice reduced body weight and ameliorates glucose homeostasis in models of diet-induced $(92,93)$ and genetic obesity (94). Batokines also include IL-6, which can be induced for example by stimulation with noradrenalin $(39,95)$. Our present results confirm that BAT stimulated with LPS releases increased amounts of IL- 6 and TNF $\alpha$. We are also the first to show that BAT produces high amounts of adiponectin and visfatin when compared to other fat pads. In particular, the high amounts of adiponectin secretion may actually contribute to the beneficial effects of BAT on insulin sensitivity also known for adiponectin (96). Future studies should evaluate the potential role of DAMPS in changing the secretory profile of batokines.

The DAMP HMGB1 acts as an endogenous proinflammatory mediator when released into the extracellular space (97) depending on its redox status (98). During turpentine-induced (aseptic) and LPS-induced inflammation HMGB1 plasma levels increase to $2-6 \mathrm{ng} / \mathrm{ml}$ (43) but locally most likely reach much higher concentrations. Here, we applied disulfide HMGB1, which acts similar to a pro-inflammatory cytokine. Not only is HMGB1 increased in plasma and fat tissue of obese subjects but also its inhibition by, for example, daily injection of HMGB1 antibodies (99) or genetic deletion of its receptor RAGE (100) reduced dietinduced obesity in mice. Moreover, HMGB1 may be involved in induction of the pro-inflammatory status in adipose tissue during obesity (45). For example, recombinant HMGB1 treatment of primary human adipocytes or a cell line of preadipocytes induced TLR4- (53) or RAGE-dependent IL-6 secretion (101). While our present results clearly show that HMGB1 can induce IL6 and also TNFa secretion, this effect occurred in a fat padspecific manner only for SAT. Thus, HMGB1 may be a more important endogenous danger signal at the barrier of the skin compared to visceral adipose tissue. In addition, we did not reveal a significant regulation of leptin and adiponectin levels in the supernatants of our cultures by HMGB1. These results are in contrast to previous findings by Montes et al. (99) who detected a significant decrease in adiponectin mRNA expression in EFAT after in vivo neutralization of HMGB1 in mice (99). This discrepancy could be due to the fact that mRNA expression levels do not always match with protein secretion and may also pertain to differences between in vivo and ex vivo model systems applied. Interestingly, HMGB1 stimulation significantly reduced the secretion of visfatin in EFAT of young and RFAT of old 
rats. Such local regulation may be regarded as a kind of local anti-inflammatory modulation. In fact, visfatin has been reported to contribute to endothelial junction disruption via HMGB1 release from endothelial cells (102), suggesting that a negative feedback mechanism on visfatin release may prevent the process from exacerbating.

Biglycan-deficient mice show reduced body weight and altered body fat composition (103). As already mentioned, its expression in adipose tissue is increased during obesity, but rather within the stromal vascular fraction than in adipocytes (42). Soluble biglycan plasma levels can be found around $200 \mathrm{ng} / \mathrm{ml}$ in healthy humans and increase [for e.g., during systemic lupus erythematosus to more than $1 \mu \mathrm{g} / \mathrm{ml}$ (104)]. Biglycan increases TNF $\alpha$ expression in macrophages, biglycandeficient mice show reduced circulating TNF $\alpha$ levels after LPSinduced severe systemic inflammation (48) and its expression in adipose tissue correlates with the expression of IL- 6 and $\mathrm{TNF} \alpha$ (42, 105). Indeed, we show for the first time that biglycan stimulates the secretion of IL-6 in EFAT (of old rats), RFAT (of young rats), and SAT (main effect), confirming the inflammatory capacity of this endogenous alarmin. Overall, the inflammatory potential was low but may contribute to the lowgrade underlying inflammation in adipose tissue during obesity. Regarding potential effects of biglycan on adipokine secretion, a previous study revealed that biglycan-deficient mice produce more adiponectin in EFAT and show higher plasma adiponectin levels (106). Our results showing that adipokine secretion was significantly reduced in EFAT of young rats are in line with this observation. Moreover, we are the first to demonstrate that biglycan can also reduce the release of visfatin from EFAT of young rats. It remains unclear why such effects by biglycan disappeared in adipose tissue of aged rats, but this observation may be related to immunosenescence of tissue resident immune cells like macrophages (107).

Overall, there exist conflicting results concerning plasma adipokine levels in aged individuals. Circulating leptin and adiponectin levels have been described to be lower (108) or higher $(109,110)$ in old age $(111,112)$. This, in turn, may be linked to variations in the definition of old age like old or very old (above 100 years), disease status, and the amount of adipose tissue $(108,109,111)$. The present data on fat explant cultures in young and old rats revealed consistent increased secretion of leptin per $g$ fat tissue in all investigated fat pads with age showing the relevance for normalization of such data toward $\mathrm{BMI} /$ fat mass and age. Adiponectin levels were only increased by age for SAT but not for the other fat pads investigated. We were also able to reveal that visfatin secretion is reduced in old age in visceral adipose tissue (EFAT, RFAT) and BAT. Possible underlying mechanisms are beyond the scope of this study and remain to be investigated in the future. However, we did find reduced expression of RAGE and TLR4 in SAT of old rats indicative for some immunosenescence with reduced receptor presence for LPS and HMGB1 and increased expression of the biglycan receptor TLR2.

Concerning the cellular source of cytokines and adipokines, previous studies have used several isolation and separation protocols revealing that the stromal vascular fraction and adipocytes differentially contribute to the total source of mediators secreted from adipose tissue. All mediators investigated here except $\mathrm{TNF} \alpha$, which is primarily produced by tissue macrophages (38), have been shown to be produced by adipocytes (113). Moreover, visfatin is also produced by macrophages or other cell types and IL- 6 as well by stromal vascular fractions cells (113). Brown adipocytes secrete batokines like adiponectin or the cytokine IL-6; less is known about the respective contribution of other cells of the stromal vascular fraction to the secretion of mediators from brown adipose tissue $(39,114)$. While the preparation of BAT was performed in the very specific interscapular localization of visually brown adipose tissue for fat explant cultures in the current study, some minor portion of beige or white adipose tissue may have contributed to secreted mediators. Thus, the exact cellular source in BAT explant cultures remains to be investigated in the future, e.g., for leptin and visfatin. Interestingly, using immunohistochemistry for $\mathrm{TNF} \alpha$ or myeloperoxidase (MPO, macrophages), we obtained evidence that macrophages indeed represent a central source of TNF $\alpha$ production within SAT (Supplementary Figure 3). In BAT, macrophage numbers did not seem to increase but may even decrease with age as revealed by immunofluorescence MPO staining (Supplementary Figure 4), suggesting that other cell types may also contribute to the source of $\mathrm{TNF} \alpha$ in this type of tissue.

It has already been shown that the expression and secretion of adipokines are dependent on fat pad-specific localization (2426). Mesenteric adipose tissue may be protective for intestinal inflammation, for example, by shaping a more anti-inflammatory macrophage phenotype (M2) $(4,63)$. Infrapatellar fat pads have also been shown to contribute to production of adipokines and cytokines during inflammatory conditions like osteoarthritis (5), and we and others have shown that adipokines modulate osteoarthritis and bone remodeling $(11,115)$. Moreover, the systemic release of these mediators during obesity modulates inflammatory insults for example in the brain; thus, some of them seem to have therapeutic potential $(10,23,116)$.

Overall, LPS strongly increased cytokine secretion but adipokine/batokine levels were not significantly affected, while DAMPs only moderately altered cytokine secretion but significantly reduced adiponectin and visfatin secretion almost exclusively in young epididymal fat pads. The expression of receptors for the exogenous PAMP LPS, namely, TLR4 (45) or RAGE (117), were reduced after LPS or HMGB1 treatment in the explant cultures, suggesting their downregulation, which is known to occur to induce tolerance effects (118). Moreover, TLR2 expression was primarily reduced by biglycan stimulation, which is in line with its signaling cascade activation.

In summary, we revealed that the endogenous DAMPs HMGB1 and biglycan can locally impact adipokine and cytokine secretion supporting the hypothesis that these mediators may be important modulators of adipose tissue inflammation that occurs during diet- or age-related obesity. Moreover, we expand on the emerging role of batokines like adiponectin, which may contribute to beneficial effects of this metabolically highly active tissue type. In the future, more insights on fat pad-specific local paracrine interactions with a multitude of organ systems 
will help to better understand fine-tuning of organ function by adipose tissue.

\section{LIMITATIONS}

Limitations of fat explant cultures pertain to the fact that only short-term cultures are meaningful, and the explant size is limited for appropriate energy and oxygen supply and the lack of functional innervation. Differential sympathetic innervation of anatomical fat pads may be needed for finetuning of side-specific function (119). Thus, more in vivo analyses will be necessary using, [for e.g., microperfusion of different fat pads to gain complementary insights into the local production of adipokines/batokines and cytokines (120)]. In addition, our current findings cannot be assigned to functional contributions of primary cultures of a defined cellular phenotype when using cultures of single-cell types. Nonetheless, previous studies support the assumption that macrophages play an important role for the inflammatory response of this type of tissue. Indeed, accumulation of macrophages in WAT is a hallmark of the low-grade inflammatory state during obesity $(10,23)$. Moreover, viability of bouts of tissue, which may differ between sources and age, is an important factor to consider when comparing different anatomical fat pads or brown and white tissue. Therefore, we have separately analyzed all types of adipose tissue as we are aware that due to blood supply or the local milieu bouts of tissue may have different properties. To prevent any local effects within one anatomical localization, tissue bouts were randomized and mixed from cranial, middle, and caudal parts of the tissue as previously reported (50) (see also the scheme/pattern for randomization in the Supplementary Materials). Here, we also show evidence for basal levels of IL-6 in all types of adipose tissue investigated in a very small and similar range, only revealing some slight differences suggesting that viability was overall similar as well. Indeed, IL-6 is produced by de novo synthesis, which prerequisites viable cells for productions and release into the supernatants (Supplementary Figure 1). In addition, intact cytoarchitecture is confirmed by hematoxylin and eosin stain of the explant tissue after culture (Supplementary Figure 2) and a vitality test using the colorimetric MTT assay confirmed the overall similar viability of anatomical fat pads (data not shown). Within the scope of the present manuscript, we did not investigate the functional significance of cytokine secretion from adipose tissue. Future studies will be needed to dissect out their contribution to changes in adipokine/batokine production. While we confirm that TNF $\alpha$ is mainly present in macrophages within the fat explants representing a crucial cell type for cytokine

\section{REFERENCES}

1. Cannon B, Nedergaard J. Brown adipose tissue: function and physiological significance. Physiol Rev. (2004) 84:277-359. doi: $10.1152 /$ physrev.00015.2003 production (Supplementary Figure 3), we did not reveal any correlation of TNF $\alpha$ levels in supernatants with adipokine secretion, suggesting that it may have a limited role in paracrine modulation of this response (Supplementary Figure 5). Similarly, IL-6 did not or only very marginally correlate with adipokine levels in the supernatants, which does not suggest any biologically significant paracrine role for IL-6-mediated modulation of adipokine secretion.

\section{DATA AVAILABILITY STATEMENT}

The raw data supporting the conclusions of this article will be made available by the authors, without undue reservation.

\section{ETHICS STATEMENT}

The animal study was reviewed and approved by Ethics committee Regional Council Giessen, ethics approval numbers GI 18/2 Nr. 1/2011, GI 18/2 Nr. 485-M, 576_M, 577_M.

\section{AUTHOR CONTRIBUTIONS}

EN, JR, KM, and CR contributed to the conception and design of the study. Ex vivo experiments and sample preparation were conducted by VP, FP, SK, TI, JR, and CR. VP performed the statistical analyses. Data analyses and interpretation were done by VP, EN, and CR. VP, EN, JR, FP, RG, SK, TI, KM, and CR contributed to writing the article and to revising the content. All authors proofread the final manuscript.

\section{FUNDING}

This work was supported by Justus Liebig University, which funds open access publication fees.

\section{ACKNOWLEDGMENTS}

We would like to thank Ms. D. Marks, Ms. D. Ott, Carina Schreiyäck, and Ms. J. Murgott for the excellent technical assistance. Data on explant culture experiments are derived from the thesis dissertation of VP (121).

\section{SUPPLEMENTARY MATERIAL}

The Supplementary Material for this article can be found online at: https://www.frontiersin.org/articles/10.3389/fimmu. 2020.01800/full\#supplementary-material 
offspring's adipose tissue. J Endocrinol. (2016) 230:39-53. doi: 10.1530/JOE16-0037

4. Kredel L, Batra A, Siegmund B. Role of fat and adipokines in intestinal inflammation. Curr Opin Gastroenterol. (2014) 30:559-65. doi: 10.1097/MOG.0000000000000116

5. Clockaerts S, Bastiaansen-Jenniskens YM, Feijt C, De Clerck L, Verhaar JA, Zuurmond AM, et al. Cytokine production by infrapatellar fat pad can be stimulated by interleukin 1 beta and inhibited by peroxisome proliferator activated receptor alpha agonist. Ann Rheum Dis. (2012) 71:1012-8. doi: 10.1136/annrheumdis-2011-200688

6. Henrichot E, Juge-Aubry CE, Pernin A, Pache JC, Velebit V, Dayer JM, et al. Production of chemokines by perivascular adipose tissue: a role in the pathogenesis of atherosclerosis? Arterioscler Thromb Vasc Biol. (2005) 25:2594-9. doi: 10.1161/01.ATV.0000188508.40052.35

7. Lee MJ, Wu Y, Fried SK. Adipose tissue heterogeneity: implication of depot differences in adipose tissue for obesity complications. Mol Aspects Med. (2013) 34:1-11. doi: 10.1016/j.mam.2012.10.001

8. Zhang Y, Proenca R, Maffei M, Barone M, Leopold L, Friedman JM. Positional cloning of the mouse obese gene and its human homologue. Nature. (1994) 372:425-32. doi: 10.1038/372425a0

9. Blum WF. Leptin: the voice of the adipose tissue. Hormone Res. (1997) 4 (Suppl. 48):2-8. doi: 10.1159/000191303

10. Aguilar-Valles A, Inoue W, Rummel C, Luheshi GN. Obesity, adipokines and neuroinflammation. Neuropharmacology. (2015) 96:124-34. doi: 10.1016/j.neuropharm.2014.12.023

11. Neumann E, Junker S, Schett G, Frommer K, Muller-Ladner U. Adipokines in bone disease. Nat Rev Rheumatol. (2016) 12:296-302. doi: $10.1038 /$ nrrheum.2016.49

12. Berg AH, Combs TP, Scherer PE. ACRP30/adiponectin: an adipokine regulating glucose and lipid metabolism. Trends Endocrinol Metab. (2002) 13:84-9. doi: 10.1016/S1043-2760(01)00524-0

13. Yamauchi T, Kamon J, Waki H, Terauchi Y, Kubota N, Hara K, et al. The fat-derived hormone adiponectin reverses insulin resistance associated with both lipoatrophy and obesity. Nat Med. (2001) 7:941-6. doi: 10.1038/90984

14. Revollo JR, Korner A, Mills KF, Satoh A, Wang T, Garten A, et al. Nampt/PBEF/Visfatin regulates insulin secretion in beta cells as a systemic NAD biosynthetic enzyme. Cell Metab. (2007) 6:363-75. doi: 10.1016/j.cmet.2007.09.003

15. Carbone F, Liberale L, Bonaventura A, Vecchie A, Casula M, Cea $M$, et al. Regulation and function of extracellular nicotinamide phosphoribosyltransferase/visfatin. Compr Physiol. (2017) 7:603-21. doi: 10.1002/cphy.c160029

16. Moschen AR, Kaser A, Enrich B, Mosheimer B, Theurl M, Niederegger $\mathrm{H}$, et al. Visfatin, an adipocytokine with proinflammatory and immunomodulating properties. J Immunol. (2007) 178:1748-58. doi: 10.4049/jimmunol.178.3.1748

17. Tsiklauri L, Werner J, Kampschulte M, Frommer KW, Berninger L, Irrgang $\mathrm{M}$, et al. Visfatin alters the cytokine and matrix-degrading enzyme profile during osteogenic and adipogenic MSC differentiation. Osteoarthritis Cartilage. (2018) 26:1225-35. doi: 10.1016/j.joca.2018.06.001

18. Yokota T, Oritani K, Takahashi I, Ishikawa J, Matsuyama A, Ouchi $\mathrm{N}$, et al. Adiponectin, a new member of the family of soluble defense collagens, negatively regulates the growth of myelomonocytic progenitors and the functions of macrophages. Blood. (2000) 96:1723-32. doi: 10.1182/blood.V96.5.1723.h8001723_1723_1732

19. Masaki T, Chiba S, Tatsukawa H, Yasuda T, Noguchi H, Seike M, et al. Adiponectin protects LPS-induced liver injury through modulation of TNF-alpha in KK-Ay obese mice. Hepatology. (2004) 40:177-84. doi: $10.1002 /$ hep. 20282

20. Lago F, Dieguez C, Gomez-Reino J, Gualillo O. The emerging role of adipokines as mediators of inflammation and immune responses. Cytokine Growth Factor Rev. (2007) 18:313-25. doi: 10.1016/j.cytogfr.2007. 04.007

21. Rummel C, Inoue W, Poole S, Luheshi GN. Leptin regulates leukocyte recruitment into the brain following systemic LPS-induced inflammation. Mol Psychiatry. (2010) 15:523-34. doi: 10.1038/mp.2009.98

22. Trayhurn P, Wood IS. Adipokines: inflammation and the pleiotropic role of white adipose tissue. Br J Nutr. (2004) 92:347-55. doi: 10.1079/BJN20041213
23. Rummel C, Bredehoft J, Damm J, Schweighofer H, Peek V, Harden LM. Obesity impacts fever and sickness behavior during acute systemic inflammation. Physiology. (2016) 31:117-30. doi: 10.1152 /physiol.00049.2015

24. Fukuhara A, Matsuda M, Nishizawa M, Segawa K, Tanaka M, Kishimoto K, et al. Visfatin: a protein secreted by visceral fat that mimics the effects of insulin. Science. (2005) 307:426-30. doi: 10.1126/science.1097243

25. Van Harmelen V, Reynisdottir S, Eriksson P, Thorne A, Hoffstedt J, Lonnqvist F, et al. Leptin secretion from subcutaneous and visceral adipose tissue in women. Diabetes. (1998) 47:913-7. doi: 10.2337/diabetes.47.6.913

26. Lihn AS, Bruun JM, He G, Pedersen SB, Jensen PF, Richelsen B. Lower expression of adiponectin mRNA in visceral adipose tissue in lean and obese subjects. Mol Cell Endocrinol. (2004) 219:9-15. doi: 10.1016/j.mce.2004.03.002

27. Krabbe KS, Pedersen M, Bruunsgaard H. Inflammatory mediators in the elderly. Exp Gerontol. (2004) 39:687-99. doi: 10.1016/j.exger.2004.01.009

28. Pedersen M, Bruunsgaard $\mathrm{H}$, Weis $\mathrm{N}$, Hendel HW, Andreassen BU, Eldrup E, et al. Circulating levels of TNF-alpha and IL-6-relation to truncal fat mass and muscle mass in healthy elderly individuals and in patients with type-2 diabetes. Mech Ageing Dev. (2003) 124:495-502. doi: 10.1016/S0047-6374(03)00027-7

29. Zhang L, Ebenezer PJ, Dasuri K, Fernandez-Kim SO, Francis J, Mariappan N, et al. Aging is associated with hypoxia and oxidative stress in adipose tissue: implications for adipose function. Am J Physiol Endocrinol Metab. (2011) 301:E599-607. doi: 10.1152/ajpendo.00059.2011

30. Ye J, Gao Z, Yin J, He Q. Hypoxia is a potential risk factor for chronic inflammation and adiponectin reduction in adipose tissue of ob/ob and dietary obese mice. Am J Physiol Endocrinol Metab. (2007) 293:E1118-28. doi: 10.1152/ajpendo.00435.2007

31. Wang B, Wood IS, Trayhurn P. Dysregulation of the expression and secretion of inflammation-related adipokines by hypoxia in human adipocytes. Pflugers Arch. (2007) 455:479-92. doi: 10.1007/s00424-007-0301-8

32. Donato AJ, Henson GD, Hart CR, Layec G, Trinity JD, Bramwell RC, et al. The impact of ageing on adipose structure, function and vasculature in the B6D2F1 mouse: evidence of significant multisystem dysfunction. J Physiol. (2014) 592:4083-96. doi: 10.1113/jphysiol.2014.274175

33. Arai Y, Takayama M, Abe Y, Hirose N. Adipokines and aging. J Atheroscler Thromb. (2011) 18:545-50. doi: 10.5551/jat.7039

34. Wu D, Ren Z, Pae M, Guo W, Cui X, Merrill AH, et al. Aging up-regulates expression of inflammatory mediators in mouse adipose tissue. J Immunol. (2007) 179:4829-39. doi: 10.4049/jimmunol.179.7.4829

35. Koenig S, Luheshi GN, Wenz T, Gerstberger R, Roth J, Rummel C. Leptin is involved in age-dependent changes in response to systemic inflammation in the rat. Brain Behav Immun. (2014) 36:128-38. doi: 10.1016/j.bbi.2013.10.019

36. Festa A, D’Agostino R Jr, Williams K, Karter AJ, Mayer-Davis EJ, Tracy $\mathrm{RP}$, et al. The relation of body fat mass and distribution to markers of chronic inflammation. Int J Obes Relat Metab Disord. (2001) 25:1407-15. doi: $10.1038 /$ sj.ijo.0801792

37. Mohamed-Ali V, Goodrick S, Rawesh A, Katz DR, Miles JM, Yudkin JS, et al. Subcutaneous adipose tissue releases interleukin-6, but not tumor necrosis factor-alpha, in vivo. J Clin Endocrinol Metab. (1997) 82:4196-200. doi: 10.1210/jc.82.12.4196

38. Weisberg SP, McCann D, Desai M, Rosenbaum M, Leibel RL, Ferrante AW Jr. Obesity is associated with macrophage accumulation in adipose tissue. $J$ Clin Invest. (2003) 112:1796-808. doi: 10.1172/JCI200319246

39. Villarroya J, Cereijo R, Gavalda-Navarro A, Peyrou M, Giralt M, Villarroya F. New insights into the secretory functions of brown adipose tissue. $J$ Endocrinol. (2019) 243:R19-27. doi: 10.1007/164_2018_119

40. Villarroya J, Cereijo R, Villarroya F. An endocrine role for brown adipose tissue? Am J Physiol Endocrinol Metab. (2013) 305:E567-72. doi: 10.1152/ajpendo.00250.2013

41. Bianchi ME. DAMPs, PAMPs and alarmins: all we need to know about danger. J Leukoc Biol. (2007) 81:1-5. doi: 10.1189/jlb.0306164

42. Kim J, Lee SK, Shin JM, Jeoun UW, Jang YJ, Park HS, et al. Enhanced biglycan gene expression in the adipose tissues of obese women and its association with obesity-related genes and metabolic parameters. Sci Rep. (2016) 6:30609. doi: $10.1038 /$ srep30609 
43. Piotrowski J, Jedrzejewski T, Pawlikowska M, Wrotek S, Kozak W. High mobility group box 1 protein released in the course of aseptic necrosis of tissues sensitizes rats to pyrogenic effects of lipopolysaccharide.J Therm Biol. (2019) 84:36-44. doi: 10.1016/j.jtherbio.2019.05.028

44. Wang H, Bloom O, Zhang M, Vishnubhakat JM, Ombrellino M, Che J, et al. HMG-1 as a late mediator of endotoxin lethality in mice. Science. (1999) 285:248-51. doi: 10.1126/science.285.5425.248

45. Wagner M. A dangerous duo in adipose tissue: high-mobility group box 1 protein and macrophages. Yale J Biol Med. (2014) 87:127-33.

46. Arrigo T, Chirico V, Salpietro V, Munafo C, Ferrau V, Gitto E, et al. Highmobility group protein B1: a new biomarker of metabolic syndrome in obese children. Eur J Endocrinol. (2013) 168:631-8. doi: 10.1530/EJE-13-0037

47. Gunasekaran MK, Viranaicken W, Girard AC, Festy F, Cesari M, Roche R, et al. Inflammation triggers high mobility group box 1 (HMGB1) secretion in adipose tissue, a potential link to obesity. Cytokine. (2013) 64:103-11. doi: 10.1016/j.cyto.2013.07.017

48. Schaefer L, Babelova A, Kiss E, Hausser HJ, Baliova M, Krzyzankova M, et al. The matrix component biglycan is proinflammatory and signals through tolllike receptors 4 and 2 in macrophages. J Clin Invest. (2005) 115:2223-33. doi: $10.1172 /$ JCI23755

49. Thalmann S, Juge-Aubry CE, Meier CA. Explant cultures of white adipose tissue. Methods Mol Biol. (2008) 456:195-9. doi: 10.1007/978-1-59745-245-8_14

50. Pohl J, Woodside B, Luheshi GN. Changes in hypothalamically mediated acute-phase inflammatory responses to lipopolysaccharide in dietinduced obese rats. Endocrinology. (2009) 150:4901-10. doi: 10.1210/en. 2009-0526

51. Simm B, Ott D, Pollatzek E, Murgott J, Gerstberger R, Rummel C, et al. Effects of prostaglandin E2 on cells cultured from the rat organum vasculosum laminae terminalis and median preoptic nucleus. Neuroscience. (2016) 313:23-35. doi: 10.1016/j.neuroscience.2015.11.034

52. Leisengang S, Ott D, Murgott J, Nurnberger F, Gerstberger R, Rummel C, et al. Effects of gabapentinoids on responses of primary cultures from rat dorsal root ganglia to inflammatory or somatosensory stimuli. J Basic Clin Physiol Pharmacol. (2020) 31:20190261. doi: 10.1515/jbcpp-2019-0261

53. Gunasekaran MK, Virama-Latchoumy AL, Girard AC, Planesse C, Guerin-Dubourg A, Ottosson L, et al. TLR4-dependant pro-inflammatory effects of HMGB1 on human adipocyte. Adipocyte. (2016) 5:384-8. doi: 10.1080/21623945.2016.1245818

54. Babelova A, Moreth K, Tsalastra-Greul W, Zeng-Brouwers J, Eickelberg $\mathrm{O}$, Young MF, et al. Biglycan, a danger signal that activates the NLRP3 inflammasome via toll-like and P2X receptors. J Biol Chem. (2009) 284:24035-48. doi: 10.1074/jbc.M109.014266

55. Dangarembizi R, Erlwanger KH, Rummel C, Roth J, Madziva MT, Harden LM. Brewer's yeast is a potent inducer of fever, sickness behavior and inflammation within the brain. Brain Behav Immun. (2018) 68:211-23. doi: 10.1016/j.bbi.2017.10.019

56. Damm J, Wiegand F, Harden LM, Gerstberger R, Rummel C, Roth J. Fever, sickness behavior, and expression of inflammatory genes in the hypothalamus after systemic and localized subcutaneous stimulation of rats with the toll-like receptor 7 agonist imiquimod. Neuroscience. (2012) 201:166-83. doi: 10.1016/j.neuroscience.2011.11.013

57. Schweighofer H, Rummel C, Roth J, Rosengarten B. Modulatory effects of vagal stimulation on neurophysiological parameters and the cellular immune response in the rat brain during systemic inflammation. Intensive Care Med Exp. (2016) 4:19. doi: 10.1186/s40635-016-0091-4

58. Wang J, Gu X, Yang J, Wei Y, Zhao Y. Gut microbiota dysbiosis and increased plasma LPS and TMAO levels in patients with preeclampsia. Front Cell Infect Microbiol. (2019) 9:409. doi: 10.3389/fcimb.2019.00409

59. Cani PD, Amar J, Iglesias MA, Poggi M, Knauf C, Bastelica D, et al. Metabolic endotoxemia initiates obesity and insulin resistance. Diabetes. (2007) 56:1761-72. doi: 10.2337/db06-1491

60. Pais de Barros JP, Gautier T, Sali W, Adrie C, Choubley H, Charron E, et al. Quantitative lipopolysaccharide analysis using HPLC/MS/MS and its combination with the limulus amebocyte lysate assay. J Lipid Res. (2015) 56:1363-9. doi: 10.1194/jlr.D059725

61. Brandtzaeg P, Bryn K, Kierulf P, Ovstebo R, Namork E, Aase B, et al. Meningococcal endotoxin in lethal septic shock plasma studied by gas chromatography, mass-spectrometry, ultracentrifugation, electron microscopy. J Clin Invest. (1992) 89:816-23. doi: 10.1172/JCI1 15660

62. Starr ME, Evers BM, Saito H. Age-associated increase in cytokine production during systemic inflammation: adipose tissue as a major source of IL-6. J Gerontol A Biol Sci Med Sci. (2009) 64:723-30. doi: 10.1093/gerona/glp046

63. Kredel LI, Batra A, Stroh T, Kuhl AA, Zeitz M, Erben U, et al. Adipokines from local fat cells shape the macrophage compartment of the creeping fat in Crohn's disease. Gut. (2013) 62:852-62. doi: 10.1136/gutjnl-2011301424

64. Starr ME, Hu Y, Stromberg AJ, Carmical JR, Wood TG, Evers BM, et al. Gene expression profile of mouse white adipose tissue during inflammatory stress: age-dependent upregulation of major procoagulant factors. Aging Cell. (2013) 12:194-206. doi: 10.1111/acel.12040

65. Leuwer M, Welters I, Marx G, Rushton A, Bao H, Hunter L, et al. Endotoxaemia leads to major increases in inflammatory adipokine gene expression in white adipose tissue of mice. Pflugers Arch. (2009) 457:731-41. doi: 10.1007/s00424-008-0564-8

66. Guo J, Liu Z, Sun H, Huang Y, Albrecht E, Zhao R, et al. Lipopolysaccharide challenge significantly influences lipid metabolism and proteome of white adipose tissue in growing pigs. Lipids Health Dis. (2015) 14:68. doi: 10.1186/s12944-015-0067-5

67. Mukesh M, Bionaz M, Graugnard DE, Drackley JK, Loor JJ. Adipose tissue depots of holstein cows are immune responsive: inflammatory gene expression in vitro. Domest Anim Endocrinol. (2010) 38:168-78. doi: 10.1016/j.domaniend.2009.10.001

68. Starr ME, Saito M, Evers BM, Saito H. Age-associated increase in cytokine production during systemic inflammation-II: the role of IL-1beta in agedependent IL-6 upregulation in adipose tissue. J Gerontol A Biol Sci Med Sci. (2015) 70:1508-15. doi: 10.1093/gerona/glu197

69. Valero N, Mosquera J, Levy A, Anez G, Marcucci R, Alvarez-Mon M. Differential induction of cytokines by human neonatal, adult, and elderly monocyte/macrophages infected with dengue virus. Viral Immunol. (2014) 27:151-9. doi: 10.1089/vim.2013.0123

70. Sakamoto T, Nitta T, Maruno K, Yeh YS, Kuwata H, Tomita K, et al. Macrophage infiltration into obese adipose tissues suppresses the induction of UCP1 level in mice. Am J Physiol Endocrinol Metab. (2016) 310:E676-87. doi: 10.1152/ajpendo.00028.2015

71. Machida K, Okamatsu-Ogura Y, Shin W, Matsuoka S, Tsubota A, Kimura K. Role of macrophages in depot-dependent browning of white adipose tissue. J Physiol Sci. (2018) 68:601-8. doi: 10.1007/s12576-017-0567-3

72. Sakamoto T, Takahashi N, Sawaragi Y, Naknukool S, Yu R, Goto T, et al. Inflammation induced by RAW macrophages suppresses UCP1 mRNA induction via ERK activation in 10T1/2 adipocytes. Am J Physiol Cell Physiol. (2013) 304:C729-38. doi: 10.1152/ajpcell.00312.2012

73. Nohr MK, Bobba N, Richelsen B, Lund S, Pedersen SB. Inflammation downregulates UCP1 expression in brown adipocytes potentially via SIRT1 and DBC1 interaction. Int J Mol Sci. (2017) 18:1006. doi: 10.3390/ijms18051006

74. Dowal L, Parameswaran P, Phat S, Akella S, Majumdar ID, Ranjan J, et al. Intrinsic properties of brown and white adipocytes have differential effects on macrophage inflammatory responses. Mediators Inflamm. (2017) 2017:9067049. doi: 10.1155/2017/9067049

75. Luheshi GN, Rummel C. Is programming of weight regulation immune to neonatal inflammation? Am J Physiol Regul Integr Comp Physiol. (2007) 293:R578-80. doi: 10.1152/ajpregu.00376.2007

76. Sarraf P, Frederich RC, Turner EM, Ma G, Jaskowiak NT, Rivet DJ, et al. Multiple cytokines and acute inflammation raise mouse leptin levels: potential role in inflammatory anorexia. J Exp Med. (1997) 185:171-5. doi: 10.1084/jem.185.1.171

77. Finck BN, Kelley KW, Dantzer R, Johnson RW. In vivo and in vitro evidence for the involvement of tumor necrosis factor-alpha in the induction of leptin by lipopolysaccharide. Endocrinology. (1998) 139:227883. doi: 10.1210/endo.139.5.6012

78. Mastronardi CA, Yu WH, Rettori V, McCann S. Lipopolysaccharideinduced leptin release is not mediated by nitric oxide, but is blocked by dexamethasone. Neuroimmunomodulation. (2000) 8:91-7. doi: $10.1159 / 000026458$ 
79. Francis J, MohanKumar PS, MohanKumar SM, Quadri SK. Systemic administration of lipopolysaccharide increases plasma leptin levels: blockade by soluble interleukin-1 receptor. Endocrine. (1999) 10:291-5. doi: 10.1007/BF02738628

80. Landman RE, Puder JJ, Xiao E, Freda PU, Ferin M, Wardlaw SL. Endotoxin stimulates leptin in the human and nonhuman primate. J Clin Endocrinol Metab. (2003) 88:1285-91. doi: 10.1210/jc.2002-021393

81. Anderson PD, Mehta NN, Wolfe ML, Hinkle CC, Pruscino L, Comiskey LL, et al. Innate immunity modulates adipokines in humans. J Clin Endocrinol Metab. (2007) 92:2272-9. doi: 10.1210/jc.2006-2545

82. Sachot C, Poole S, Luheshi GN. Circulating leptin mediates lipopolysaccharide-induced anorexia and fever in rats. J Physiol. (2004) 561:263-72. doi: 10.1113/jphysiol.2004.074351

83. Rummel C, Inoue W, Sachot C, Poole S, Hubschle T, Luheshi GN. Selective contribution of interleukin-6 and leptin to brain inflammatory signals induced by systemic LPS injection in mice. J Comp Neurol. (2008) 511:37395. doi: 10.1002/cne.21850

84. Mastronardi CA, Yu WH, Srivastava VK, Dees WL, McCann SM. Lipopolysaccharide-induced leptin release is neurally controlled. Proc Natl Acad Sci USA. (2001) 98:14720-5. doi: 10.1073/pnas.251543598

85. Iwasa T, Matsuzaki T, Matsui S, Tungalagsuvd A, Munkhzaya M, Takiguchi E, et al. The sensitivity of adipose tissue visfatin mRNA expression to lipopolysaccharide-induced endotoxemia is increased by ovariectomy in female rats. Int Immunopharmacol. (2016) 35:243-47. doi: 10.1016/j.intimp.2016.04.002

86. Prabhakar U, Conway TM, Murdock P, Mooney JL, Clark S, Hedge P, et al. Correlation of protein and gene expression profiles of inflammatory proteins after endotoxin challenge in human subjects. DNA Cell Biol. (2005) 24:410-31. doi: 10.1089/dna.2005.24.410

87. Jia SH, Li Y, Parodo J, Kapus A, Fan L, Rotstein OD, et al. Pre-B cell colonyenhancing factor inhibits neutrophil apoptosis in experimental inflammation and clinical sepsis. J Clin Invest. (2004) 113:1318-27. doi: 10.1172/JCI19930

88. Pini M, Castellanos KJ, Rhodes DH, Fantuzzi G. Obesity and IL-6 interact in modulating the response to endotoxemia in mice. Cytokine. (2013) 61:71-7. doi: 10.1016/j.cyto.2012.08.027

89. Tsuchihashi H, Yamamoto H, Maeda K, Ugi S, Mori T, Shimizu $\mathrm{T}$, et al. Circulating concentrations of adiponectin, an endogenous lipopolysaccharide neutralizing protein, decrease in rats with polymicrobial sepsis. J Surg Res. (2006) 134:348-53. doi: 10.1016/j.jss.2006.01.001

90. Tvarijonaviciute A, Eralp O, Kocaturk M, Yilmaz Z, Ceron JJ. Adiponectin and IGF-1 are negative acute phase proteins in a dog model of acute endotoxaemia. Vet Immunol Immunopathol. (2011) 140:147-51. doi: 10.1016/j.vetimm.2010.11.011

91. Keller P, Moller K, Krabbe KS, Pedersen BK. Circulating adiponectin levels during human endotoxaemia. Clin Exp Immunol. (2003) 134:107-10. doi: 10.1046/j.1365-2249.2003.02264.x

92. Liu X, Zheng Z, Zhu X, Meng M, Li L, Shen Y, et al. Brown adipose tissue transplantation improves whole-body energy metabolism. Cell Res. (2013) 23:851-4. doi: 10.1038/cr.2013.64

93. Stanford KI, Middelbeek RJ, Townsend KL, An D, Nygaard EB, Hitchcox $\mathrm{KM}$, et al. Brown adipose tissue regulates glucose homeostasis and insulin sensitivity. J Clin Invest. (2013) 123:215-23. doi: 10.1172/JCI 62308

94. Liu X, Wang S, You Y, Meng M, Zheng Z, Dong M, et al. Brown adipose tissue transplantation reverses obesity in Ob/Ob mice. Endocrinology. (2015) 156:2461-9. doi: 10.1210/en.2014-1598

95. Cannon B, Houstek J, Nedergaard J. Brown adipose tissue. more than an effector of thermogenesis? Ann N Y Acad Sci. (1998) 856:171-87. doi: 10.1111/j.1749-6632.1998.tb08325.x

96. Yadav A, Kataria MA, Saini V, Yadav A. Role of leptin and adiponectin in insulin resistance. Clin Chim Acta. (2013) 417:80-4. doi: 10.1016/j.cca.2012.12.007

97. Lotze MT, Tracey KJ. High-mobility group box 1 protein (HMGB1): nuclear weapon in the immune arsenal. Nat Rev Immunol. (2005) 5:331-42. doi: $10.1038 /$ nri1594

98. Janko C, Filipovic M, Munoz LE, Schorn C, Schett G, Ivanovic-Burmazovic I, et al. Redox modulation of HMGB1-related signaling. Antioxid Redox Signal. (2014) 20:1075-85. doi: 10.1089/ars.2013.5179
99. Montes VN, Subramanian S, Goodspeed L, Wang SA, Omer M, Bobik A, et al. Anti-HMGB1 antibody reduces weight gain in mice fed a high-fat diet. Nutr Diabetes. (2015) 5:e161. doi: 10.1038/nutd.2015.11

100. Song F, Hurtado del Pozo C, Rosario R, Zou YS, Ananthakrishnan R, Xu X, et al. RAGE regulates the metabolic and inflammatory response to high-fat feeding in mice. Diabetes. (2014) 63:1948-65. doi: 10.2337/db13-1636

101. Nativel B, Marimoutou M, Thon-Hon VG, Gunasekaran MK, Andries J, Stanislas G, et al. Soluble HMGB1 is a novel adipokine stimulating IL-6 secretion through RAGE receptor in SW872 preadipocyte cell line: contribution to chronic inflammation in fat tissue. PLoS ONE. (2013) 8:e76039. doi: 10.1371/journal.pone.0076039

102. Chen Y, Pitzer AL, Li X, Li PL, Wang L, Zhang Y. Instigation of endothelial Nlrp3 inflammasome by adipokine visfatin promotes inter-endothelial junction disruption: role of HMGB1. J Cell Mol Med. (2015) 19:2715-27. doi: $10.1111 / \mathrm{jcmm} .12657$

103. Tang T, Thompson JC, Wilson PG, Nelson C, Williams KJ, Tannock LR. Decreased body fat, elevated plasma transforming growth factor-beta levels, and impaired BMP4-like signaling in biglycan-deficient mice. Connect Tissue Res. (2013) 54:5-13. doi: 10.3109/03008207.2012.715700

104. Moreth K, Brodbeck R, Babelova A, Gretz N, Spieker T, Zeng-Brouwers $\mathrm{J}$, et al. The proteoglycan biglycan regulates expression of the $\mathrm{B}$ cell chemoattractant CXCL13 and aggravates murine lupus nephritis. J Clin Invest. (2010) 120:4251-72. doi: 10.1172/JCI42213

105. Adapala VJ, Ward M, Ajuwon KM. Adipose tissue biglycan as a potential anti-inflammatory target of sodium salicylate in mice fed a high fat diet. $J$ Inflamm. (2012) 9:15. doi: 10.1186/1476-9255-9-15

106. Ward MG, Ajuwon KM. Biglycan deletion alters adiponectin expression in murine adipose tissue and 3T3-L1 adipocytes. PLoS ONE. (2012) 7:e50554. doi: 10.1371/journal.pone.0050554

107. Pfister G, Savino W. Can the immune system still be efficient in the elderly? An immunological and immunoendocrine therapeutic perspective. Neuroimmunomodulation. (2008) 15:351-64. doi: 10.1159/0001 56477

108. Baranowska B, Wolinska-Witort E, Bik W, Baranowska-Bik A, Martynska L, Broczek K, et al. Evaluation of neuroendocrine status in longevity. Neurobiol Aging. (2007) 28:774-83. doi: 10.1016/j.neurobiolaging.2006.03.014

109. Roszkowska-Gancarz M, Jonas M, Owczarz M, Kurylowicz A, Polosak J, Franek E, et al. Age-related changes of leptin and leptin receptor variants in healthy elderly and long-lived adults. Geriatr Gerontol Int. (2015) 15:365-71. doi: 10.1111/ggi.12267

110. Obata Y, Yamada Y, Takahi Y, Baden MY, Saisho K, Tamba S, et al. Relationship between serum adiponectin levels and age in healthy subjects and patients with type 2 diabetes. Clin Endocrinol. (2013) 79:204-10. doi: $10.1111 /$ cen.12041

111. Schautz B, Later W, Heller M, Peters A, Muller MJ, Bosy-Westphal A. Impact of age on leptin and adiponectin independent of adiposity. Br J Nutr. (2012) 108:363-70. doi: 10.1017/S0007114511005605

112. Coimbra S, Brandao Proenca J, Santos-Silva A, Neuparth MJ. Adiponectin, leptin, and chemerin in elderly patients with type 2 diabetes mellitus: a close linkage with obesity and length of the disease. BioMed Res Int. (2014) 2014:701915. doi: 10.1155/2014/701915

113. Ouchi N, Parker JL, Lugus JJ, Walsh K. Adipokines in inflammation and metabolic disease. Nat Rev Immunol. (2011) 11:85-97. doi: 10.1038/nri2921

114. Wang W, Seale P. Control of brown and beige fat development. Nat Rev Mol Cell Biol. (2016) 17:691-702. doi: 10.1038/nrm.2016.96

115. Junker S, Frommer KW, Krumbholz G, Tsiklauri L, Gerstberger R, Rehart S, et al. Expression of adipokines in osteoarthritis osteophytes and their effect on osteoblasts. Matrix Biol. (2017) 62:75-91. doi: 10.1016/j.matbio.2016.11.005

116. Rummel C. Inflammatory transcription factors as activation markers and functional readouts in immune-to-brain communication. Brain Behav Immun. (2016) 54:1-14. doi: 10.1016/j.bbi.2015.09.003

117. Yamamoto Y, Harashima A, Saito H, Tsuneyama K, Munesue S, Motoyoshi S, et al. Septic shock is associated with receptor for advanced glycation end products ligation of LPS. J Immunol. (2011) 186:3248-57. doi: 10.4049/jimmunol.1002253

118. Seeley JJ, Ghosh S. Tolerization of inflammatory gene expression. Cold Spring Harb Symp Quant Biol. (2013) 78:69-79. doi: 10.1101/sqb.78.020040 
119. Sipe LM, Yang C, Ephrem J, Garren E, Hirsh J, Deppmann CD. Differential sympathetic outflow to adipose depots is required for visceral fat loss in response to calorie restriction. Nutr Diabetes. (2017) 7:e260. doi: 10.1038/nutd.2017.13

120. Dostalova I, Kavalkova P, Haluzikova D, Housova J, Matoulek M, Haluzik $\mathrm{M}$. The use of microdialysis to characterize the endocrine production of human subcutaneous adipose tissue in vivo. Regul Pept. (2009) 155:156-62. doi: 10.1016/j.regpep.2009.03.008

121. Peek V. Das Potential Von Endogenen "Toll-Like" Rezeptor-Agonisten und Omega-3-Fettsäuren zur Modulation Systemischer Entzündungsreaktionen. Giessen: VVB Laufersweiler Verlag, Justus Liebig University Giessen (2017). $304 \mathrm{p}$.
Conflict of Interest: The authors declare that the research was conducted in the absence of any commercial or financial relationships that could be construed as a potential conflict of interest.

Copyright (C) 2020 Peek, Neumann, Inoue, Koenig, Pflieger, Gerstberger, Roth, Matsumura and Rummel. This is an open-access article distributed under the terms of the Creative Commons Attribution License (CC BY). The use, distribution or reproduction in other forums is permitted, provided the original author(s) and the copyright owner(s) are credited and that the original publication in this journal is cited, in accordance with accepted academic practice. No use, distribution or reproduction is permitted which does not comply with these terms. 